\title{
A glossary for biometeorology
}

\author{
Simon N. Gosling • Erin K. Bryce • P. Grady Dixon • Katharina M. A. Gabriel • \\ Elaine Y. Gosling • Jonathan M. Hanes • David M. Hondula • Liang Liang • \\ Priscilla Ayleen Bustos Mac Lean • Stefan Muthers • Sheila Tavares Nascimento • \\ Martina Petralli • Jennifer K. Vanos • Eva R. Wanka
}

Received: 30 October 2012 /Revised: 22 August 2013 / Accepted: 26 August 2013 / Published online: 19 February 2014

(C) The Author(s) 2013. This article is published with open access at Springerlink.com

\begin{abstract}
Here we present, for the first time, a glossary of biometeorological terms. The glossary aims to address the need for a reliable source of biometeorological definitions, thereby facilitating communication and mutual understanding in this rapidly expanding field. A total of 171 terms are defined, with reference to 234 citations. It is anticipated that the glossary will
\end{abstract}

be revisited in coming years, updating terms and adding new terms, as appropriate. The glossary is intended to provide a useful resource to the biometeorology community, and to this end, readers are encouraged to contact the lead author to suggest additional terms for inclusion in later versions of the glossary as a result of new and emerging developments in the field.

\author{
S. N. Gosling $(\bowtie)$ \\ School of Geography, University of Nottingham, Nottingham NG7 \\ 2RD, UK \\ e-mail: simon.gosling@nottingham.ac.uk \\ E. K. Bryce \\ Department of Anthropology, University of Toronto, \\ Toronto, ON, Canada \\ P. G. Dixon \\ Department of Geosciences, Mississippi State University, Starkville, \\ MS, USA

\section{K. M. A. Gabriel} \\ Department of Social Epidemiology, Institute for Public Health and \\ Nursing Research, University of Bremen, Bremen, Germany

\section{K. M. A. Gabriel} \\ Berlin School of Public Health, Charité-Universitätsmedizin Berlin, \\ Berlin, Germany

\section{E. Y. Gosling} \\ School of Civil and Building Engineering and Loughborough Design \\ School, Loughborough University, Loughborough, UK
}

\section{J. M. Hanes}

Department of Geography, University of Wisconsin-Milwaukee, Milwaukee, WI, USA

\section{M. Hondula}

Center for Policy Informatics, School of Public Affairs, Arizona State University, Phoenix, AZ, USA

\author{
L. Liang \\ Department of Geography, University of Kentucky, Lexington, \\ KY, USA \\ P. A. Bustos Mac Lean \\ Department of Animal Science, Universidade Estadual de Maringá \\ (UEM), Maringa, Paraná, Brazil \\ S. Muthers \\ Climate and Environmental Physics, Physics Institute and Oeschger \\ Centre for Climate Change Research, University of Bern, Bern, \\ Switzerland \\ S. T. Nascimento \\ Department of Animal Science, Faculty of Agrarian and Veterinarian \\ Sciences, São Paulo State University (UNESP), São Paulo, Brazil
}

\section{Petralli}

Interdepartmental Centre of Bioclimatology and Department of Agrifood Production and Environmental Sciences,

University of Florence, Florence, Italy

\section{J. K. Vanos}

Department of Geosciences, Texas Tech University, Lubbock, TX, USA

E. R. Wanka

University of Munich, Munich, Germany 
Keywords Glossary $\cdot$ Definition · Agricultural and forest meteorology $\cdot$ Air pollution · Animal biometeorology . Biometeorological indices · Epidemiology $\cdot$ Phenology Statistics · Temperature-related health · Urban climatology · Urban meteorology

\section{Addressing an important need in biometeorology}

In any interdisciplinary subject, there is a danger that component individual disciplines will become so specialised that researchers will no longer be able to communicate with each other meaningfully. "Biometeorology", defined as "An interdisciplinary science that considers the interactions between atmospheric processes and living organisms (plants, animals and humans)" [International Society of Biometeorology (ISB) 2013; McGregor 2012b], brings together research from such diverse disciplines including, but not limited to, geography, biology, mathematics and statistics, environmental science, and physiology, requires its practitioners to be conversant in a wide range of disciplines. At the 18th International Congress of Biometeorology in Tokyo, Japan, in 2008, members of the Executive Board of the ISB agreed that a glossary of commonly used biometeorology terms would be a useful tool to facilitate communication in this rapidly expanding field. The Students and New Professionals Group (SNP) of the ISB accepted the opportunity to compile the glossary, which is presented here. This is the first time a glossary has been created specifically for biometeorology.

This glossary presents terms and concepts that are most frequently encountered in the biometeorological literature, with the goal of explaining how these terms are used by biometeorologists. The glossary is meant to be accessible; that is, intelligible to an educated audience who may not be familiar with specific biometeorological terminology and who want to know how the terms are used in context. Where appropriate, references are provided, to aid further reading around the topic if the reader wishes. For a more comprehensive list of meteorology terms only, readers should consult the American Meteorological Society Glossary of Meteorology (AMS 2013). For epidemiological terms only, readers are referred to A Dictionary of Epidemiology (Porta 2008).

Terms are listed alphabetically; 171 terms are defined, with reference to 234 citations. The glossary generally adopts an encyclopaedic approach, whereby the first sentence of each term is a stand-alone definition, and is followed by how that term is used in biometeorological research. A number of equations are presented in the glossary. A common notation is used throughout for the various terms that appear in more than one equation. These are listed in Table 1. All terms that include a definition elsewhere in the glossary are crosslinked.

The glossary is published here and on the website of the ISB (http://www.biometeorology.org). It is anticipated that the glossary will be revisited in coming years, updating terms and
Table 1 Common notation applied throughout the glossary for the various terms that appear in more than one equation

\begin{tabular}{ll}
\hline Symbol & Definition \\
\hline$T_{\mathrm{g}}$ & $\quad \begin{array}{r}\text { Black globe temperature }\left({ }^{\circ} \mathrm{C}\right) \text {, sometimes referred to as the } \\
\text { Vernon globe temperature }\left({ }^{\circ} \mathrm{C}\right) \text {, or the globe temperature }\left({ }^{\circ} \mathrm{C}\right)\end{array}$ \\
$v$ & Wind speed $\left(\mathrm{ms}^{-1}\right)$ \\
$R$ & Relative humidity $(\%)$ \\
$T_{\mathrm{w}}$ & Wet bulb temperature $\left({ }^{\circ} \mathrm{C}\right)$ \\
$T_{\mathrm{d}}$ & Dew point temperature $\left({ }^{\circ} \mathrm{C}\right)$ \\
$T_{\mathrm{a}}$ & Dry bulb temperature $\left({ }^{\circ} \mathrm{C}\right)$, commonly referred to as the air \\
& $\quad$ temperature $\left({ }^{\circ} \mathrm{C}\right)$ \\
$T_{\text {mrt }}$ & Mean radiant temperature $\left({ }^{\circ} \mathrm{C}\right)$ \\
$\mathrm{VP}$ & Vapour pressure $(\mathrm{hPa}$ or $\mathrm{kPa}$, depending upon equation $)$ \\
$M$ & Metabolic rate $\left(\right.$ internal heat production) $\left(\mathrm{Wm}{ }^{-2}\right)$ \\
\hline
\end{tabular}

adding new terms as appropriate. It is hoped that this glossary will be a tool that keeps ISB members together in the spirit of interdisciplinary study and collegiality that is the hallmark of biometeorology. Readers of the glossary are encouraged to contact the lead author to suggest additional terms for inclusion in the glossary.

\section{Selection of terms for inclusion in the glossary}

The initial challenge in compiling the glossary was to identify the terms to include. Rather than pick terms randomly, the authors first defined nine categories central to biometeorological research, under which terms could be grouped. These were: agricultural and forest meteorology, air pollution, animal biometeorology, biometeorological indices, epidemiology, phenology, statistics and related terms, temperature-related health, and urban climatology and meteorology. Each coauthor then independently contributed terms that they considered should be included within each category, in a collaborative online document. Since each co-author was able to view, edit and add terms to each category on the online document continuously, this facilitated a virtual conversation regarding which terms should be included as well as whether they appeared in the appropriate category.

After all co-authors had contributed the terms they wanted, the terms were divided randomly among the group of coauthors for defining. This approach is preferable, and more robust than each co-author defining only terms they contributed or are familiar with, because it encourages each co-author to research the terms in a comprehensive manner and to draw upon a range of references as appropriate. When all the coauthors had defined the terms randomly assigned to them, the complete list of all terms and definitions was distributed amongst all co-authors for internal review. This presented the opportunity for category experts within the group to check 
the definitions for scientific accuracy. To this end, all coauthors commented upon and edited the complete list of terms and definitions. The lead author then compiled all of the terms into a version that was presented at the 19th International Congress of Biometeorology in December 2011, where attendees were welcomed to provide comments and suggestions for the Glossary. The Glossary was then further edited and subsequently submitted to International Journal of Biometeorology where it underwent peer review following the protocol of the journal. The first submission was reviewed by eight peer-reviewers including the Editor-in-Chief. Following this stage of peer review, it was decided to list all the terms in alphabetical order instead of under category names. The glossary presented here has therefore undergone a rigorous peer review process, which confirms its integrity and robustness as a source of information for the Biometeorological community.

\section{The glossary}

\section{Acclimatisation}

The process by which a living organism becomes adapted to a change of climatic environment (AMS 2013). Acclimatisation is a relatively quick adaptation that occurs within the organism's lifetime. Traditionally, acclimatisation studies in humans have focused on adapting to temperature changes (such as moving from a temperate climate to the tropics), but acclimatisation can also occur with a change in altitude, photoperiod and humidity, for instance.

\section{Adaptation}

Adaptation in human systems is defined by the Intergovernmental Panel on Climate Change (IPCC 2012b) as "The process of adjustment to actual or expected climate and its effects, in order to moderate harm or exploit beneficial opportunities". In natural systems, the IPCC (2012b) defines adaptation as the process of adjustment to actual climate and its effects, and notes that human intervention may facilitate adjustment to the expected climate. In temperature-mortality modelling studies, adaptation includes physiological acclimatisation to warmer/colder temperatures, as well as a range of behavioural adaptations (e.g. dressing appropriately during hot/cold weather) and technological adaptations [e.g. air-conditioning, the introduction of heat health warning systems (HHWS), and the adaptation of infrastructure such as the construction of green roofs to reduce urban heat island (UHI) magnitude]. Most temperature-related mortality studies refer only to physiological acclimatisation and there is much debate as to how adaptation should be modelled (Gosling et al. 2009).
Aerobiological forecast

A forecast that examines aerobiological elements (usually pollen and fungal spores) to evaluate the risk of disease development (such as allergies or asthma) (Laaidi 2001). See also biometeorological forecast.

\section{Aerobiology}

Aerobiology is the study of organisms and other biological material (such as bacteria, fungal spores, pollen grains and viruses) that are transported through the atmosphere (Singh and Mathur 2012). The transmission of airborne diseases is one of the most important medical applications of aerobiology on human and animal health.

Aerodynamic resistance

Also known as drag, aerodynamic resistance is the force the air exerts on an object that is parallel and opposite to the object's direction of flow relative to the object. In other words, the resistance of the air to the movement of an object through it. Aerodynamic resistance affects the transfer of water from the evaporating surface into the air above the forest canopy.

Age-standardisation

A technique that is used to remove as much as possible the effects of differences in age or other confounding factors in comparing two or more populations To compare populations, the observed age-specific variables are compared to some standard population (e.g. world average, national average, etc.). Agestandardised mortality rates are commonly used in biometeorology research so that causes of death can be analysed in multiple locations that might have significantly different age distributions.

Air quality indices

An aggregated evaluation of the pollutant load of the atmosphere across multiple constituents, generally developed to compare environmental conditions to biological outcomes with an emphasis on human health. The indices also provide a concise method of informing the general public regarding atmospheric conditions by incorporating a suite of pollutants into one single measure. The method of aggregation varies from index to index, with some emphasising the single pollutant observed at the highest/most threatening concentration, whereas others consider the effects of all pollutants simultaneously (Kyrkilis et al. 2007). In the US, the Air Quality Index is determined by the maximum concentration of ozone, particulate pollution, carbon monoxide, sulphur dioxide, and nitrogen dioxide, where the concentration of each pollutant is normalized on a unitless $1-500$ scale, where a value of 100 
corresponds to the relevant national ambient air quality standard. The overall index value is set as that associated with the highest normalised score for any individual variable (Bishoi et al. 2009). A similar system based on the pollutant with the highest relative concentration is used in the UK, but values are converted to a 1-10 scale for communication to the public (Holgate 2011).

\section{Air temperature distribution in urban areas}

Similar to the UHI effect (urban versus rural), temperature is not distributed evenly within a single urban area. Air temperature is affected by such elements as surface cover (pavement vs grass, for example), building height, and anthropogenic heat. In general, rivers and parks are cooler than built-up areas during the day. Air temperature differences within the urban environment reach a peak during night-time (Petralli et al. 2011). Urban parks are often cooler than their surroundings (Spronken-Smith and Oke 1999) and the magnitude and timing of the park cool island (PCI) effect varies with park type and the extent to which the park differs from its surroundings (Spronken-Smith and Oke 1998).

\section{Albedo}

Albedo (reflection coefficient) represents the reflective property of a surface. It is defined as the ratio of reflected shortwave radiation from the surface to incident shortwave radiation upon it. It is a dimensionless quantity that may also be expressed as a percentage, and it is measured on a scale from zero (surface with no reflecting power of a perfectly black surface) to 1 (perfect reflection of a white surface). Albedo is sometimes referred to as the reflection coefficient $(\alpha)$.

\section{Allometric scaling}

The quantification of biological scaling relationships between two measured quantities. The scaling may be applied to morphological traits (e.g. the relationship between brain size and body size among adult humans), physiological traits (e.g. the relationship between metabolic rate and body size among mammal species) or ecological traits (e.g. the relationship between wing size and flight performance in birds) (Shingleton 2010). For example, the dependence of a biological variable $(Y)$ on body mass $(m)$ is often characterised by an allometric scaling law of:

$\mathrm{Y}=\mathrm{Y}_{0} \mathrm{~m}^{\mathrm{b}}$

where

$b \quad$ is the scaling exponent

$Y_{0}$ is a constant that is characteristic of the kind of organism (West et al. 1997).
Allen's rule

A paradigm for morphological adaptation that relates extremity length of mammals to environmental conditions. Heat loss occurs more readily through the peripheries, therefore shorter limbs are often found in colder climates whereas longer limbs are found in climates where heat dissipation is required (Tilkens et al. 2007). The rule was originally proposed by Allen (1877) who observed physiological differences in members of a species inhabiting different latitudes (Lindsay 1987).

\section{Allergenic pollen}

An allergy is a sensitivity to a normally harmless substance and some people possess an allergy to plant pollen, known as pollinosis, or more commonly 'hay fever' (ICD-10: J30.1). Allergenic pollens are those that cause pollinosis. Grass pollen is the major cause of pollinosis in many parts of the world (Freidhoff et al. 1986). Other sources of allergenic pollens include trees [birch is the major pollen-allergen-producing tree in northern Europe (Eriksson and Holmen 1996)], weeds [Parietaria is the main allergenic genus of the Urticaceae (nettle) family (D'Amato et al. 2007) and ragweed is the major allergenic pollen in North America] and ornamental plants [e.g. weeping fig, yucca, ivy, palm tree and geranium (Mahillon et al. 2006)].

\section{Animal welfare}

The relationship between climate and animals influences animal welfare. The welfare of an individual is their status in relation to their attempts to adapt to their environment (Broom 1991). The quality of the environment and climate that surrounds the animal will directly influence their ability to maintain levels of welfare and thereby also whether they achieve optimal production. When an animal does not have the necessary resources to prevent thermal stress, there will be disruption in homeostasis, which may cause a state of stress, resulting in physiological problems of growth, reproductivity, immunological function, and in extreme cases even death (Henry 1992). One way to define animal welfare is to verify the biological functioning of the animal, to ensure that the animal can keep their bodily functions in balance, are able to grow and reproduce normally, are free from diseases and injuries, and that they present no signs of bad nutrition or abnormal behaviours and physiological responses. Welfare can also be assessed by physiological and behavioural characteristics, with physiological characteristics between species usually compared by allometric scaling. The respiratory rate, heart rate and rectal temperature are the main physiological measures assessed in quantifying the welfare of animals under unfavourable thermal environmental conditions. 
Apparent temperature

A generic term used to cover a range of biometeorological indices that estimate an individual's perceived temperature, based upon the air temperature and humidity and/or wind speed. It represents how the climate "feels" to the human body (Robinson 2001). The term was put forwards by Steadman (1979a, b). Examples of apparent temperature indices include: the Heat Index (HI), the Heat Stress Index (HSI), Humidex, Wet Bulb Globe Temperature (WBGT), Universal Thermal Climate Index (UTCI), the Steadman Apparent Temperature Index and the New Wind Chill Equivalent Temperature (WCET) index. While the term "apparent temperature" is generic, it should be noted that some studies refer to the Steadman Apparent Temperature Index and the HI as the "apparent temperature".

Bagged classification trees / tree ensembles

A statistical technique that creates an ensemble by drawing sub-samples from the original sample. A decision tree is trained using the permutations, and each tree becomes a member of the ensemble. This method is meant to enhance the accuracy of unstable decision-tree learning methods. "Bagged" is an abbreviation of the employed method of "bootstrap aggregation."

\section{Baseline mortality}

The majority of climate-health studies do not report raw mortality data but, in order to give an indication of the mortality attributable to climate, an excess mortality is estimated by subtracting the expected mortality from the observed mortality (Gosling et al. 2007). The expected mortality is often called the baseline mortality.

\section{Benzene}

A double-bonded aromatic hydrocarbon $\left(\mathrm{C}_{6} \mathrm{H}_{6}\right)$ arranged in a ring structure. Benzene is a known carcinogen. Outdoor exposures frequently arise from vehicle exhaust, hazardous waste sites, and industrial processes. Indoor exposures arise from household products including glues, paints, and detergents (CDC 2011).

\section{Bergmann's rule}

An ecogeographic principle established by Bergmann (1847). It states that, within a broadly distributed genus, species of larger size are found in colder environments, and species of smaller size are found in warmer regions. The causation is seen in the adapted heat balance of animals. Although the rule fits to numerous species (e.g. wolves, foxes, deer, eagle owl) there are also a lot of exceptions.

\section{Biometeorology}

The International Society of Biometeorology (ISB) (2013) defines biometeorology as "An interdisciplinary science that considers the interactions between atmospheric processes and living organisms (plants, animals and humans)." The central question within the field is "how does weather and climate impact the well-being of all living creatures?" (ISB 2013). Please refer to McGregor (2012b) for the latest progress report on this field (at the time this glossary was published).

Biometeorological forecast

Forecasting efforts to predict meteorological conditions relevant to human wellbeing such as health and comfort using theoretical models with corresponding indices (Morabito et al. 2008). Examples include: aerobiological forecasts, which focus on pollen/allergy season predictions; forecasts for the Universal Thermal Climate Index (UTCI) (Novak 2013); the Heat Index (Ebi et al. 2004); and the New Wind Chill Equivalent Temperature (WCET) Index (NOAA 2011).

\section{Budburst}

The seasonal phenological event of a deciduous plant when the first leaves are unfolded from the bud. This is often reported as a date for the purpose of comparing inter-annual variations, especially with respect to climate change effects on vegetation (Lebourgeois et al. 2010; Menzel 2000).

\section{Carbon flux}

The rate (mass/time) of carbon transfer into, out of, or within environmental systems.

\section{Carbon sink}

An environmental system that accumulates carbon over long time periods.

\section{Carbon source}

A process or system that releases more carbon into the atmosphere than it assimilates (Running 2008).

Cardiovascular and respiratory diseases related to air pollution

A number of stresses to the cardiovascular and respiratory systems have been linked to elevated atmospheric pollutant 
concentrations. Research to date has particularly emphasised relationships with ozone and particulate matter. Specific diseases linked with air pollution include those labelled as "Diseases of the circulatory system" and "Diseases of the respiratory system" in the ICD-10 classification (codes I00-I99 and J00-J99 respectively), especially heart failure, heart rhythm disturbances, cerebrovascular events, ischemic heart disease, peripheral vascular disease, chronic obstructive pulmonary disease, respiratory tract infections, pneumonia, and influenza (Dominici et al. 2006; Sunyer et al. 1996; Wong et al. 2002).

\section{Chilling}

See "Vernalisation".

\section{Chi-square test}

Measure of the goodness-of-fit, typically between a dataset and expected distribution. The test is applicable for both discrete and continuous data; however, for continuous data the observations must be grouped into "bins." The frequency of occurrence of observations in each bin or classification is compared to the expected number of occurrences based on a theoretical distribution. The test statistic is expressed as:

$\chi^{2}=\sum_{n \text { classes }} \frac{(\# \text { Observed }-\# \text { Expected })^{2}}{\# \text { Expected }}$

Where observed and expected refer to a specific number of observations within each of $n$ classes. The test statistic is compared to the chi-square distribution to determine statistical significance (Wilks 1995).

\section{Classification and regression trees}

Classification and regression trees (C\&RT or CART) are a recursive partitioning method used to predict dependent variables that are either continuous (regression) or categorical (classification). The classic algorithm was developed by Breiman et al. (1984). Data are assigned into binary categories based on a set of logical if-then statements (the branches of the "tree"). Rules are selected to differentiate observations as much as possible based on the dependent variable. Once a rule is selected, the same process is applied to each node. Partitioning stops at a set point or when no more useful divisions can be made. C\&RT is a useful method because the decisions are often intuitive, it is simple enough that new observations can be classified easily, and it makes no assumption that the underlying relationship between the dependent and independent variables is linear.
Conductive heat transfer

The rate at which heat energy is transferred between a unit area of two surfaces (e.g. human and chair) with the temperature difference being maintained. Usually expressed in units of $\mathrm{Wm}^{-2}{ }^{\circ} \mathrm{C}^{-1}$ (IUPS Thermal Commission 2001).

\section{Confounding factors}

Epidemiological studies investigate the causes of particular health outcomes based on associations with different risk factors that are recorded in the study. The risk factors are often selected a priori. Whilst a given study will investigate particular exposures, the risk of developing the health outcome can be affected by other factors. In some cases, these factors may ultimately be responsible for some or all of the deduced relationship between health outcomes and exposure variables of interest. This distortion leads to an invalid comparison and the distorting factors are called confounding factors or confounding variables. As an example, with studies that investigate the relationship between increasing daily air temperature (the exposure variable) and heat-related mortality (the outcome variables), confounding factors that are often included are daily air pollution and relative humidity (Baccini et al. 2011; Ma et al. 2011; Porta 2008).

\section{Cold-related mortality}

Cold-related mortality is conflating deaths occurring during the cold season and deaths attributed to cold. The latest ICD-10 codes (WHO 2011b) that consider cold-related causes are included in L50.2 (urticaria due to cold), P80 (cold injury syndrome), T33.0-T35.0 (superficial frostbite), T68 (hypothermia) and X31 (exposure to excessive natural cold causing hypothermia). Most cold related deaths occur due to hypothermia [core temperature drops below $35^{\circ} \mathrm{C}$, which is below the temperature range specified for a normal active state (IUPS Thermal Commission 2001)]. However, there is no uniformly accepted definition of what constitutes a cold-related death, as additional deaths due to other primary causes occur. Epidemiological evidence indicates such causal relationships of cold weather with mortality (Keatinge et al. 2000; Martin et al. 2012), with excess mortality related to cold associated with ischaemic heart disease, cerebro-vascular disease, respiratory disease, and influenza (Hassi 2005; McGregor 2005; Näyhä et al. 2011; Ou et al. 2011). Cold-related mortality is highest $1-2$ weeks after a cold spell occurs (Anderson and Bell 2009; Martin et al. 2012). Hypothermia is preventable, and public health strategies tailored to vulnerable populations to cold aids in reducing hypothermiarelated morbidity and mortality rates. Three risk factors for this are advanced age ( $>65$ years), mental impairment, and substance abuse (CDC 2005). 


\section{Contingency table}

A table that summarises the observed cross-tabulated frequencies of two or more variables, each of which has a limited number of outcomes. Each cell in the contingency table contains a specific count of instances where each variable was observed simultaneously (e.g. individuals with a certain risk factor who experienced a certain outcome). An example is shown in Table 2.

\section{Convective heat transfer}

The net rate of heat transfer between a human and the ambient environment. Free convection develops due to thermal gradients between air temperature and skin temperature; hence, convective heat loss occurs when air temperature is less than skin temperature, and convective heat gain occurs when air temperature is greater than that of the skin. Forced convection can also occur due to fans, pumps, or body movement and is usually expressed in terms of unit area, i.e. as a heat flux $\left(\mathrm{Wm}^{-2}\right)$ (IUPS Thermal Commission 2001).

\section{Cooling degree-day}

Cooling degree-day (CDD) is calculated by summing the number of degrees below an average hourly outdoor "threshold" temperature, for a 1-day (24-h) period. A threshold temperature for cooling of $18.3^{\circ} \mathrm{C}$ represents an ASHRAE (2001) standard numerical value, and is the commonly used value (ASHRAE 2005; NOAA 2013; Watts and Kalkstein 2004), although ASHRAE (2005) also use a threshold of $10{ }^{\circ} \mathrm{C}\left(\mathrm{CDD}_{10}\right)$. Annual CDDs represent the sum of the degree-days throughout one calendar year. CDD also accounts for ambient temperature fluctuations associated with a temperature drop after a cold frontal passage or subsequent to a thunderstorm, bringing relief from heat stress (Watts and Kalkstein 2004).

\section{Correlation}

Correlation is a statistical method used to analyse the strength of association between variables (Snedecor and Cochran 1980). The measure used to describe this relationship is the

Table 2 An example contingency table

\begin{tabular}{lllll}
\hline & Condition A & Condition B & Condition C & Total \\
\hline Group 1 & $\mathrm{d}$ & $\mathrm{e}$ & $\mathrm{f}$ & $\mathrm{d}+\mathrm{e}+\mathrm{f}$ \\
Group 2 & $\mathrm{g}$ & $\mathrm{h}$ & $\mathrm{i}$ & $\mathrm{g}+\mathrm{h}+\mathrm{i}$ \\
Total & $\mathrm{d}+\mathrm{g}$ & $\mathrm{e}+\mathrm{h}$ & $\mathrm{f}+\mathrm{i}$ & $\mathrm{d}+\mathrm{e}+\mathrm{f}+\mathrm{g}+\mathrm{h}+\mathrm{i}$ \\
\hline
\end{tabular}

correlation coefficient (r), a unitless number with values between -1 and 1 . Positive values of $r$ describe the tendency of two variables to increase together, while negative values describe the reverse behaviour. In the case where no relationship is found for two variables, the correlation coefficient is zero. Different methods exist to calculate the correlation coefficient. The most common is the Pearson product-moment correlation coefficient. A correlation describes only a statistical association between two variables, not cause and effect.

\section{Cutaneous evaporation}

It is a common mistake to confound the definitions of cutaneous evaporation with perspiration (sweat rate). Birds have no sweat glands, while pigs have a limited number in the surface of the body, which are not responsive to thermal stimuli. Cutaneous evaporation can occur through insensible perspiration due to the permeability of the epidermis to the passage of liquids from inside the body (Da Silva and Maia 2013). Around $50 \%$ of total evaporation occurs via insensible perspiration in some birds when exposed to high temperatures (Lasiewski et al. 1971). Sweat rate is the secretion of a liquid (sweat) by specialised cells. Animals that have sweat glands (cattle, sheep, goats) present both insensible perspiration and perspiration.

\section{Degree-day}

The difference in temperature between the outdoor mean temperature over a $24-\mathrm{h}$ period and a given baseline (or threshold temperature) (ASHRAE 2005), which can differ depending on the purpose or study. Such purposes include calculations related to energy consumption (Arnell et al. 2013), building envelope requirements (ASHRAE 2005), fueling demand information (NOAA 2013), and extreme weather stress (Watts and Kalkstein 2004). The degree-day is the basis for calculating both the cooling degree-day (CDD), heating degree-day (HDD) and growing degree-day (GDD).

\section{Endemic}

In epidemiology, an endemic is a disease that persists constantly in a given human population without the need for external inputs. The exact prevalence rate of an endemic disease may vary over time, but it is always present at a rate greater than zero (Porta 2008).

In biogeography, an endemic organism is exclusively native to a place or biota. Endemic organisms are typically found on remote islands (e.g. Hawaii), rugged highlands (e.g. Ethiopia) or endorheic water bodies (e.g. Lake Baikal). 
Heat balance of homeothermic animals

Livestock animals are homeothermic (chickens, sheep, goats, pigs, cattle) and are able to maintain a constant body temperature, regulating their production of heat by their metabolism and the losses with the surrounding environment. The body temperature varies for each species: chickens $\left(41.0^{\circ} \mathrm{C}\right)$, sheep $\left(38.5^{\circ} \mathrm{C}\right)$, goats $\left(39.0^{\circ} \mathrm{C}\right)$, pigs $\left(38.0^{\circ} \mathrm{C}\right)$ and cattle $\left(38.0^{\circ} \mathrm{C}\right)$. As environmental temperature changes, the animals adjust their physiology and behaviour in an attempt to keep their body temperature constant (DeShazer et al. 2009). Sensible heat losses occur by convection, conduction and radiation, and latent heat losses occur by respiration and from the skin surface (sweat rate and insensible perspiration). The mechanisms involved in heat gain and losses between animals and the environment are summarised in Fig. 1.

\section{Epidemic}

Observation of an unusually high occurrence of cases of a certain disease within a given human population, during a given period and restricted to a certain locale. The magnitude of the occurrence of cases varies with the disease and describes a substantial exceedance of what is expected based on recent experience. A large increase in the rate of disease can move it from endemic to epidemic, such as obesity in the US (Mokdad et al. 1999).

\section{Emissivity}

The ability to radiate energy. Emissivity is commonly measured as the ratio of a material's energy radiated to that of a black body (i.e. a perfect emitter) at the same temperature. Darker objects tend to have a higher emissivity while reflective objects have a lower emissivity.

Equivalent temperature index for cows

The effects of temperature, humidity and wind speed on the thermal balance of dairy cows were combined by Baeta et al. (1987) in an equation termed the equivalent temperature index (ETI, $\left.{ }^{\circ} \mathrm{C}\right)$ :

$$
\begin{aligned}
E T I= & 27.88-0.456 \mathrm{~T}_{\mathrm{a}}+0.010754 \mathrm{~T}_{\mathrm{a}}^{2}+0.4905 \mathrm{R} \\
& +0.00088 \mathrm{R}^{2}+1.1507 \mathrm{v}-0.126447 \mathrm{v}^{2} \\
& +0.019876 R T_{\mathrm{a}}+0.046313 v T_{\mathrm{a}}
\end{aligned}
$$

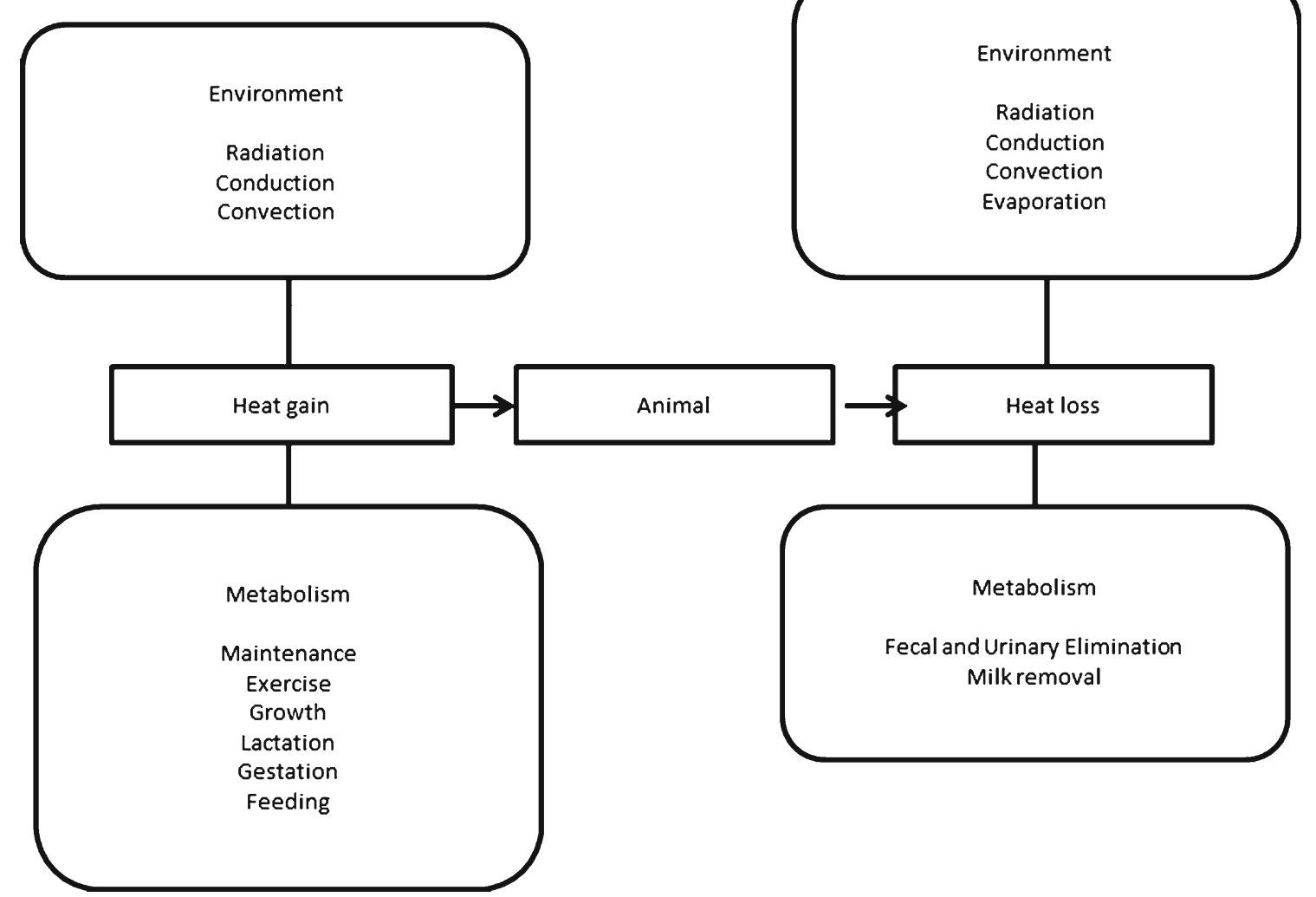

Fig. 1 Mechanisms of heat gains and losses between homeothermic animals and the environment. Adapted from Fuquay (1981) 
where:

$T_{\mathrm{a}} \quad$ is the air temperature $\left({ }^{\circ} \mathrm{C}\right)$

$R \quad$ is the relative humidity (\%)

$v \quad$ is the wind speed $\left(\mathrm{ms}^{-1}\right)$.

This index was calibrated from data with high producing Holstein cows exposed to changing environmental conditions (temperatures ranging between $16{ }^{\circ} \mathrm{C}$ and $41{ }^{\circ} \mathrm{C}$ ). Results indicated that an increase in the value of ETI up to $41^{\circ} \mathrm{C}$ from thermo-neutral conditions can be associated with a decrease of $38 \%$ in milk production, and elevated rectal temperature to $40.8^{\circ} \mathrm{C}$. To this end, the following ETI values are considered as representing a damaging risk to animals:

No problems: $18^{\circ} \mathrm{C}$ to $<27^{\circ} \mathrm{C}$

Caution: $27^{\circ} \mathrm{C}$ to $<32{ }^{\circ} \mathrm{C}$

Extreme caution: $32{ }^{\circ} \mathrm{C}$ to $<38^{\circ} \mathrm{C}$

Danger: $38^{\circ} \mathrm{C}$ to $<44{ }^{\circ} \mathrm{C}$

Extreme danger: $>=44{ }^{\circ} \mathrm{C}$

\section{EuroHEAT}

EuroHEAT was a project that quantified the health effects of heat in European cities and identified options for improving health systems' preparedness for, and response to, the effects of heat-waves. The project, running from 2005 to 2007, was coordinated by WHO/Europe and co-funded by the European Commission (EC) Directorate-General for Health and Consumers (WHO 2013).

\section{European climate assessment \& dataset project}

The objective of the European climate assessment \& dataset (ECA\&D) project is to combine collation of daily series of observations at meteorological stations, quality control, analysis of extremes and dissemination of both the daily data and the analysis results. The project has compiled a number of definitions and mathematical formulas of meteorological indices used in the ECA\&D project (note, however, that these are not biometeorological indices). The ECA\&D indices can be viewed at: http://eca.knmi.nl/indicesextremes/ indicesdictionary.php.

Evaporative heat gain or loss (evaporative heat transfer)

Most commonly occurs as a loss, whereby heat is used for sweat to change phase from liquid to vapour. This consumes heat in the form of latent heat of vapourisation, with heat being transferred from the body to the air, causing cooling to occur. A gain occurs when heat is transferred from the air to the body when heat is released due to condensation on the skin. Expressed in units of $\mathrm{Wm}^{-2}$.
Frost day

A day when the daily minimum temperature is at, or below, freezing $\left(0^{\circ} \mathrm{C} ; 32^{\circ} \mathrm{F}\right)$ at a particular location (Moonen et al. 2002). The last frost day in the spring and the first frost day in the autumn can be used to define the beginning and end of the climatological growing season (Menzel et al. 2003). These two events can be measured using thresholds other than $0{ }^{\circ} \mathrm{C}$ $\left(32^{\circ} \mathrm{F}\right)$ and have also been used to define the frost period.

Frost period

The amount of time between the first frost day in autumn and the last frost day in spring (Schwartz and Reiter 2000).

Generalised additive model

Generalised additive models (GAMs) assume that the mean of the dependent variable depends on an additive predictor through a nonlinear link function. GAMs permit the response probability distribution to be any member of the exponential family of distributions. For example, the non-linear link may be, for instance, Poisson or Gaussian in nature. This gives rise to methods such as Poisson regression modelling and loess smoothing, which are common in epidemiological studies on the association between temperature and mortality rates, for instance (Gouveia et al. 2003).

Greenhouse gases and the greenhouse effect

Many chemical compounds present in Earth's atmosphere are relatively poor absorbers of shortwave radiation but strong absorbers of longwave radiation, thus keeping the lower atmosphere and surface environment warmer than they otherwise would be given Earth's solar constant. This radiative mechanism has been termed the "greenhouse effect" and responsible atmospheric constituents labelled "greenhouse gases." According to the IPCC (2007), the most important greenhouse gases are water vapour and carbon dioxide, whilst nitrogen and oxygen - the two most abundant constituents of the atmosphere-have no effect. Many greenhouse gases occur naturally in the atmosphere (e.g. carbon dioxide, methane, water vapour) but others are synthetic, such as chlorofluorocarbons (CFCs), hydrofluorocarbons (HFCs) and perfluorocarbons (PFCs). Human activity can intensify the greenhouse effect through the emission of greenhouse gases. For instance, the amount of carbon dioxide in the atmosphere has increased by about $35 \%$ in the industrial era, due largely to the combustion of fossil fuels and removal of forests (IPCC 2007). 
Growing degree-day

Growing degree-day (GDD) is a heat unit, expressed in units of ${ }^{\circ} \mathrm{C}$-day. GDD aims to describe the heat energy received by a given plant over a given time period. It is often argued that the calculation of GDD in plant phenology and development science has greatly improved the description and prediction of phenological events compared to approaches such as number of days or time of year, for instance (Richardson et al. 2006). GDD is usually calculated by the following equation (McMaster and Wilhelm 1997):

$G D D=\left[\left(\mathrm{T}_{\max }+\mathrm{T}_{\min }\right) / 2\right]-\mathrm{T}_{\text {base }}$

where:

$T_{\max }$ is the daily maximum air temperature $\left({ }^{\circ} \mathrm{C}\right)$

$T_{\min }$ is the daily minimum air temperature $\left({ }^{\circ} \mathrm{C}\right)$

$T_{\text {base }}$ is the temperature below which the process of interest does not progress $\left({ }^{\circ} \mathrm{C}\right)$.

In some cases, for simplification, $\left[\left(T_{\max }+\mathrm{T}_{\min }\right) / 2\right]$ is set equal to daily average temperature. $T_{\text {base }}$ varies among plant species and it is also likely to be dependent upon the growth stage being considered. Similarly the heat accumulation can also be measured at hourly frequency to generate growing degree hours (GDH). GDD and GDH can also be summed cumulatively over time as a measure of accumulated heat received by plants (Chuine 2000; Richardson et al. 2006).

\section{Growing season}

Annual period when temperate plants experience active growth outside of the winter dormancy. The start and end of a growing season is marked with a seasonal rise and drop of air temperatures, often using the last and first frost days (Schwartz 2003).

Heat health warning system

A heat health warning system (HHWS) is a system, usually initiated by public health authorities, to reduce the health impacts of heat waves. It consists of two main components: one is responsible for the identification and forecasting of heat waves with serious health impacts, and a second initiates and coordinates public health measurements to mitigate the most serious health impacts of the heat wave effect (Kovats and Ebi 2006; WHO 2004).

Heat index

An apparent temperature calculation designed to determine the temperature that the human body "feels" when its evaporative cooling mechanism (perspiration) is limited due to increased relative humidity. The variables required to calculate the heat index (HI) were established originally by Steadman (1979b), but the current operational equation was created through multiple regression statistical analyses by Rothfusz (1990):

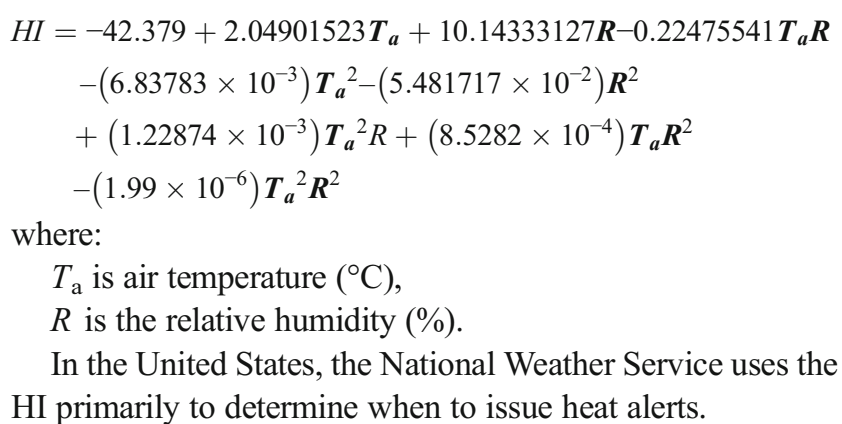

Heating degree-day

Heating degree-day (HDD) is calculated by summing the number of degrees above an average hourly outdoor "threshold" temperature, for a 1-day (24-h) period. The ASHRAE (2001) standard is $18.3^{\circ} \mathrm{C}$, also used by NOAA (2013) for fuelling demand, and for building cooling requirements by ASHRAE (2005) in addition to a HDD at a $10{ }^{\circ} \mathrm{C}$ (HDD10) threshold. Annual HDDs represent the sum of the degree-days throughout one calendar year.

Heat load index

Gaughan et al. (2008) proposed this thermal comfort index for feedlot beef cattle in Australia. It can be calculated for two different environmental conditions:

(1) For $T_{\mathrm{g}}<25^{\circ} \mathrm{C}$ :

$$
H L I=10.66+0.28 \mathrm{R}+1.3 \mathrm{~T}_{\mathrm{g}}-\mathrm{v}
$$

(2) For $T_{\mathrm{g}}>25^{\circ} \mathrm{C}$ :

$$
H L I=8.62+0.38 \mathrm{R}+1.55 \mathrm{~T}_{\mathrm{g}}-0.5 \mathrm{v}+\mathrm{e}^{2.4-\mathrm{v}}
$$

where:

$T_{\mathrm{g}} \quad$ is the black globe temperature $\left({ }^{\circ} \mathrm{C}\right)$

$v \quad$ is the wind speed $\left(\mathrm{ms}^{-1}\right)$

$R \quad$ is the relative humidity (\%).

Based upon these equations, the environment is classified as thermoneutral ( $\mathrm{HLI} \leq 70.0$ ), warm (HLI is 70.1 to 77.0$)$, hot (HLI is 77.1 to 86.0 ) or very hot (HLI>86).

Heat-related mortality

Heat-related mortality is conflating deaths occurring during the warm season and deaths attributed to heat. The latest ICD10 codes (WHO 2011b) that consider heat-related causes of 
death are included in T67 (effects of heat and light), which incorporates T67.0 (heatstroke and sunstroke), T67.1 (heat syncope), T67.2 (heat cramp), T67.3 (heat exhaustion, anhydrotic), T67.4 (heat exhaustion due to salt depletion), T67.5 (heat exhaustion, unspecified), T67.6 (heat fatigue, transient), T67.7 (heat oedema), T67.8 (other effects of heat and light) and T67.9 (effect of heat and light, unspecified). These have been used in recent studies; e.g. Beggs and Vaneckova (2008) but the majority of studies tend to calculate "excess mortality" (Gosling et al. 2009) from time series of all-cause mortality, or from other causes (e.g. ischemic heart disease).

Heat stress index

A summer apparent temperature index (May-Sept) that computes relative heat stress comparisons of locations throughout the US, based on 30-year datasets and deviations from normal (Watts and Kalkstein 2004). It is different from the Index of Heat Stress. The heat stress index (HSI) uses the "shaded" Steadman Apparent Temperature index (Steadman 1984), cloud cover, cooling degree-days, and consecutive days of extreme heat to calculate a relative heat stress for individual locations at specific times of the warm season (Souch and Grimmond 2004). This is completed by evaluating the frequency distributions for 10-day intervals derived from the meteorological variables, with percentile values determined for each parameter. The final daily HSI (\%) is based on the location of the daily summed value under the distribution curve (Watts and Kalkstein 2004). For example, a HSI of $97 \%$ conveys that on the current date, only $3 \%$ of days are likely to experience more stressful conditions than the day being reviewed.

\section{Heat stroke}

Typically refers to classical heat stroke (CHS) - a dangerous and potentially fatal condition in which an individual's core body temperature rises to a temperature above $40.0^{\circ} \mathrm{C}$ as a result of exposure to high ambient air temperature. At this temperature, other key internal functions are compromised, including the central nervous system, which may result in hallucinations, convulsions, or coma. Exertional heat stroke (EHS) is diagnosed in cases where high core temperatures are caused by a high level of physical activity (potentially in combination with high environmental temperature) (Bouchama and Knochel 2002).

Heat tolerance index

A measure of the ability of certain animals to tolerate incoming solar radiation. Rauschenbach and Yerokhin (1975) proposed equations to calculate heat tolerance index (HTI) for three different species:

- For cattle: $\mathrm{HTI}=1.2 T_{\mathrm{a}}-20 \mathrm{~d}+52$

- For sheep: HTI $=1.0 T_{\mathrm{a}}-20 \mathrm{~d}+60$

- For pigs: $\mathrm{HTI}=1.4 T_{\mathrm{a}}-20 \mathrm{~d}+44$

where:

$T_{\mathrm{a}} \quad$ is the air temperature $\left({ }^{\circ} \mathrm{C}\right)$

$\mathrm{d}$ is the difference between the rectal temperature measurements in the morning ( 0900 hours) and afternoon (1500 hours). During this period, the animals remain exposed to direct solar radiation.

Heat wave

A heat wave is a period of extreme high temperature that lasts several days. Heat waves can be responsible for large numbers of weather-related deaths and diseases (Kovats and Ebi 2006). No globally accepted definition of a heat wave exists (Koppe et al. 2004; Robinson 2001). Three different approaches are usually applied to determine whether a period is defined as a "heat wave" (Gosling et al. 2009; Robinson 2001). Methods for identifying heat wave days include selecting the 95th percentile of daily temperature (Beniston 2004; Gosling et al. 2007; Hajat et al. 2002), selecting absolute temperatures (Koppe and Jendritzky 2005; Matzarakis et al. 2010) [this approach is mostly used with human biometeorological indices such as the Physiological Equivalent Temperature (PET) or the Universal Thermal Climate Index (UTCI), for which levels of thermal stress are defined (e.g. Matzarakis et al. $(2010$; 2009) for PET)], or approaches that identify a specific synoptic classification/air mass (Hondula et al. 2013). For farm animals, a heat wave has been defined as a period of at least 3 consecutive days during which recovery hours are less than 10, where the recovery hours are defined as hours with a temperature humidity index (THI) below 72 (Valtorta et al. 2002).

\section{HeRATE}

HeRATE (Health Related Assessment of the Thermal Environment) is a procedure that can be used with human biometeorological indices to consider short-term adaptation in thermal stress assessments (Koppe and Jendritzky 2005). It is based on levels of thermal stress and a conceptual model, which allows for short-term acclimatisation and adaptation through behavioural and societal measures by adjusting the levels of thermal stress based on the thermal conditions of the preceding weeks. In the heat health warning system (HHWS) of the German Weather Service (DWD), HeRATE is used together with the human biometeorological index, perceived temperature (PT). 


\section{Homeostasis}

The ability of an organism to maintain a state of internal stability or equilibrium within a dynamic ambient environment. In biometeorology, this is most often in reference to humans or other animals, and their ability to maintain a healthy body temperature in hot or cold conditions.

Human heat balance equation (energy budget)

A mathematical equation that describes the net flow rate of exchanges of heat (gains and losses) to a human in a given environment. The conceptual heat balance equation (Parsons 2010) is:

$\mathrm{M}-\mathrm{W}=\mathrm{E}+R H E+\mathrm{C}+\mathrm{K}+\mathrm{S}$

where:

$\begin{array}{ll}\mathrm{M} & \text { is the metabolic rate }\left(\mathrm{Wm}^{-2}\right) \\ \mathrm{W} & \text { is the mechanical work done by the body }\left(\mathrm{Wm}^{-2}\right) \\ \mathrm{E} & \text { is the evaporative heat gain or loss }\left(\mathrm{Wm}^{-2}\right) \\ \mathrm{RHE} & \text { is the radiant heat exchange }\left(\mathrm{Wm}^{-2}\right) \\ \mathrm{C} & \text { is the convective heat transfer }\left(\mathrm{Wm}^{-2}\right) \\ \mathrm{K} & \text { is the conductive heat transfer }\left(\mathrm{Wm}^{-2}{ }^{\circ} \mathrm{C}^{-1}\right) \\ \mathrm{S} & \text { is the net heat storage }\left(\mathrm{Wm}^{-2}\right) .\end{array}$

When the rate of heat storage is zero $(S=0)$, the body is in heat balance (i.e. constant temperature). If there is a net heat gain (loss) then storage will be positive (negative) and the body temperature will increase (decrease) (Parsons 2010).

\section{Humidex}

The preferred apparent temperature calculation method in Canada. Unlike the heat index, which is used in the US, Humidex (short for "humidity index") uses dewpoint temperature rather than relative humidity in the calculation (Masterson and Richardson 1979). The Humidex equation is:

Humidex $=T_{a}+\frac{5}{9}\left(6.11 \times \exp ^{5417.7530\left(\frac{1}{273.16}-\frac{1}{T_{d}}\right)}-10\right)$

where:

$T_{\mathrm{a}}$ is air temperature $\left({ }^{\circ} \mathrm{C}\right)$

$T_{\mathrm{d}}$ is dew point temperature $\left({ }^{\circ} \mathrm{C}\right)$.

Incidence

The number of new cases of a disease or condition in a population within a specific time period. A sudden large increase in incidence would be classified as an epidemic.
Index of heat stress

First introduced by Belding and Hatch (1955) based on the fact that required evaporative heat loss $\left(E_{\text {req }}\right)$ and maximum evaporation $\left(E_{\max }\right)$ together incorporate all components of thermal stress. The Index of Heat Stress is calculated by the following equation:

Index of Heat Stress $=\left(E_{\text {req }} / E_{\text {max }}\right) \times 100$.

If the index of heat stress is less than $100 \%$, sweat evaporation can match $E_{\text {req, }}$, and body temperature can be controlled. If the index of heat stress is greater than $100 \%$, sweat evaporation, and cooling, is limited to $E_{\max }$ (Brotherhood 2008). Hence, evaporative heat cannot be lost, and heat is stored in the body, core temperature rises, and heat stress is likely. The index of heat stress differs from the heat stress index (HSI).

Indoor air quality

Refers to the constituents of the air inside a building or enclosed space, which affects the health of the users. This is of increasing concern as humans are spending greater amounts of time indoors where harmful gases and particles can be produced and then accumulate. Pollutants are released into the air from a variety of source activities (e.g. building materials, work/home tasks and activities, heating, painting, cleaning) (US Environmental Protection Agency 2010). Locations of highest concern are those involving prolonged, continued exposure, such as home, school, and workplace (US Environmental Protection Agency 2010). Measuring and monitoring types of particles and gases of concern - such as moulds and allergens, radon, carbon monoxide, volatile organic compounds, asbestos fibres, $\mathrm{NO}_{\mathrm{x}}$, carbon dioxide, and ozone-can determine indoor air quality. Computer modelling of ventilation and other airflow in buildings can predict air quality levels. Outdoor air may penetrate indoors via the ventilation systems of buildings, and thus must also be taken into consideration (Hang et al. 2009). In developing countries, carbon monoxide is a pollutant of high concern, affecting indoor air quality and occupant health in the home. This is due to the burning of any fuel such as gas, oil, kerosene, wood, or charcoal for cooking and heating (Duflo et al. 2008). Proper ventilation, filtration, and source control are the most used methods for diluting and improving indoor air quality and comfort, with control of high temperature and humidity also important (US Environmental Protection Agency 2010). 
International Organization for Standardization standards

The International Organization for Standardization (ISO) is a network of national standards bodies that represents the world's largest developer of voluntary International Standards. The British Standards Institution (BSI) is the UK's National Standards Body and is responsible for producing and publishing British Standards and for representing UK interests in international and European standards organsations such as ISO. ISO documents are developed as international standards and documented as "ISO [Standard Number]". Once ISO documents are published, they can be republished by individual countries as a national adoption. For example, when the EU adopt an ISO Standard, the letters "EN" are added to the document name, e.g. "EN ISO [Standard Number]". Following adoption, the documents may be produced officially in different languages (e.g. English by the BSI), which adds an extra part to the document name, such as "BS EN ISO [Standard Number]" in the UK, or "DIN EN ISO [Standard Number]" in Germany, for instance. There are several ISO Standards for Assessing Thermal Environments.

International Organization for Standardization standards for assessing thermal environments

ISO standards for assessing thermal environments can be divided into three categories: hot, moderate and cold (Orosa and Oliveira 2012; Parsons 2006).

For hot environments, the ISO standards include:

- $\quad$ BS EN ISO 27243:1994, ISO 7243:1989 (British Standards Institution 1994; Parsons 2006) for the estimation of heat stress based on the Wet Bulb Globe Temperature (WBGT).

- BS EN ISO 7933:2004 (British Standards Institution 2005a) for the analytical determination and interpretation of heat stress using calculation of the predicted heat strain.

- BS EN ISO 9886:2004 (British Standards Institution 2004) for the evaluation of thermal strain by physiological measurements. Also applicable to cold and moderate environments.

- BS EN ISO 13732-1:2008 (British Standards Institution $2009 b$ ) for methods for the assessment of human responses to contact with hot surfaces.

For moderate environments, the ISO standards include:

- $\quad$ BS EN ISO 7730:2005 (British Standards Institution 2006) for the analytical determination and interpretation of thermal comfort using calculation of the Predicted Mean Vote (PMV) and Predicted Percent Dissatisfied (PPD) indices and local thermal comfort criteria.

- BS EN ISO 10551:2001 (British Standards Institution 2002a) for the assessment of the influence of the thermal environment using subjective judgement scales.
- BS EN ISO 9886:2004 (British Standards Institution 2004) for the evaluation of thermal strain by physiological measurements. Also applicable to hot and cold environments.

- BS EN ISO 13732-2:2001 (British Standards Institution 2013) for methods for the assessment of human responses to contact with moderate temperature surfaces.

For cold environments, the ISO standards include:

- BS EN ISO 11079:2007 (British Standards Institution 2008) for the determination and interpretation of cold stress when using required clothing insulation and local cooling effects.

- BS EN ISO 9886:2004 (British Standards Institution 2004) for the evaluation of thermal strain by physiological measurements. Also applicable to hot and moderate environments.

- BS EN ISO 13732-3:2008 (British Standards Institution 2009c) for methods for the assessment of human responses to contact with cold temperature surfaces.

International Classification of Diseases 10th revision: ICD-10

The international standard diagnostic classification used for all general epidemiological and many health management purposes as well as for clinical use. The 10th revision, published in 2006 by WHO, is the latest in a series, which has its origins in the 1850s. In ICD-10 an alphanumerical system was introduced to code diseases and other health problems.

Example:

$\mathrm{J}$ : Diseases of the respiratory system

J30: Vasomotor and allergic rhinitis

J30.1: Allergic rhinitis due to pollen (hay fever, pollinosis).

\section{Klima Michel model}

The Klima Michel model (KMM) is an energy-balance-model for the human body, based on the predicted mean vote (PMV) equation of Fanger (1972) and the PMV correction of Gagge et al. (1986), that considers latent heat fluxes in a more appropriate way. Contrary to PMV, the KMM takes the complex outdoor radiant conditions into account (Jendritzky et al. 1979, 1990). In the KMM, the energy-balance (see Munich energy balance model for individuals; MEMI) is solved for a standard person of 35 years and $1.75 \mathrm{~m}$ tall, with a weight of $75 \mathrm{~kg}$ and a physical heat production of $135 \mathrm{~W}$, which corresponds to walking at approximately $4 \mathrm{~km} \mathrm{~h}^{-1}$. Depending on the thermal conditions, the person adapts their clothing to between 0.5 and 1.75 clo. 
Landsat

Landsat is a NASA program, with the mission to provide repetitive acquisition of high-resolution multispectral data of the Earth's surface on a global basis by remote sensing (NASA 2013). The data from the Landsat spacecraft constitute the longest record of the Earth's continental surfaces as seen from space. The program has been providing data since 1972. According to NASA, no other current or planned remote-sensing system, public or private, fills the role of Landsat in global change research or in civil and commercial applications (NASA 2013). Landsat 8 , is the latest mission in the Landsat series. Landsat 8 provides synoptic coverage of continental surfaces with spectral bands in the visible, near-infrared, short-wave, and thermal infrared regions of the electromagnetic spectrum and with moderate-resolution (15 m-100 m) (NASA 2013).

Landscape phenology

An approach to seasonal vegetation dynamics that integrates phenological patterns (mainly spatial) and processes (mainly temporal) within heterogeneous biophysical environments across multiple scales (Liang and Schwartz 2009).

Land surface phenology

Seasonal pattern of variation in vegetated land surfaces observed from remote sensing (Friedl et al. 2006).

\section{Latent heat}

The energy required to change the state of a substance at a constant temperature (Thakore and Bhatt 2007). In atmospheric science, the three most common values are:

- Latent heat of vaporisation (condensation) is equal to $2,257 \mathrm{~kJ} \mathrm{~kg}^{-1}$ at $100{ }^{\circ} \mathrm{C}\left(2,501 \mathrm{~kJ} \mathrm{~kg}^{-1}\right.$ at $\left.0{ }^{\circ} \mathrm{C}\right)$ and is the amount of energy absorbed (released) by water during evaporation (condensation) (Allaby 2002).

- Latent heat of melting (fusion) is equal to $334 \mathrm{~kJ} \mathrm{~kg}^{-1}$ at $0{ }^{\circ} \mathrm{C}$ and is the amount of energy absorbed (released) by water during melting (freezing) (Allaby 2002).

- Latent heat of sublimation is equal to $2,835 \mathrm{~kJ} \mathrm{~kg}^{-1}$ at $0{ }^{\circ} \mathrm{C}$ and is the amount of energy absorbed (released) by ice (water vapour) during sublimation (Allaby 2002).

Latent heat flux in animals

When the gradient of temperature between the body surface of an animal and the environment decreases, latent heat fluxes become important for maintenance of body temperature.
These losses depend on a differential of vapour pressures between the ambient air and the expired air of the animal (Maia et al. 2005). These losses can occur by respiration and cutaneous evaporation. The importance and contribution of respiration and cutaneous evaporation differ between species (Da Silva and Maia 2013). For instance, around $76 \%$ of total latent heat flux in poultry can be attributed to respiration (Richards 1976) and the exposure of cattle to high temperatures can lead to an exponential increase of latent heat losses (both respiratory and cutaneous) (Maia et al. 2005).

\section{Leaf area index}

Leaf area index (LAI) is a dimensionless value used to specify the area of assimilation of a plant by its leaf area $\left(\mathrm{m}^{2}\right)$ per ground area $\left(\mathrm{m}^{2}\right)$.

$L A I=\frac{\text { leaf area }\left(\mathrm{m}^{2}\right)}{\text { ground area }\left(\mathrm{m}^{2}\right)}$

Flat leaves are considered to have one side; in conifers the total surface of a needle is counted. The values of LAI typically range from 0 for bare ground to 5 to 6 in broadleaved forests of the temperate zone and up to 10 for rainforests in the tropics. The index is able to determine primary production and thus is important for modelling the $\mathrm{CO}_{2}$ balance, but also for estimating the influence of vegetation on run-off.

Leaf flushing

Shoots developing in a terminal bud on a branch. There can be several flushes of growth during a season as each new shoot experiences growth on its terminal bud (Elliott et al. 2006).

\section{Leaf wetness}

The liquid water present on the surface of a leaf due to atmospheric deposition or condensation (Klemm et al. 2002).

Loess smoothing

Loess or lowess stands for "locally weighted smoothing". It can be applied through the use of a generalised additive model (GAM). The technique can accommodate nonlinear and nonmonotonic functions, thus offering a flexible nonparametric modelling tool. In loess, each observed value is replaced by a predicted value, generated by connecting the central point from a weighted regression for a given span (neighbourhood) of the data (Hastie and Tibshirani 1990). The polynomial is fitted using weighted least squares, giving more weight to points near the point whose response is being estimated and less weight to points further away. 
Maximum evaporation $\left(E_{\max }\right)$ (evaporative capacity)

The maximum amount of evaporation possible from the body given the prevailing environmental conditions (measured in $\mathrm{Wm}^{-2}$ ). If $E_{\max }<\mathrm{E}_{\text {req }}$ (required evaporative heat loss) then sweat evaporation is limited and inefficient sweating occurs. If $E_{\max }>E_{\text {req }}$, evaporative cooling can occur.

\section{Mean radiant temperature}

The mean radiant temperature $\left(T_{\mathrm{mrt}}\right)$ is a parameter that combines all longwave and shortwave radiant fluxes to a single value. It is defined as the temperature of a surrounding black body that causes the same radiant heat fluxes as the complex radiant fluxes (Fanger 1972). In human biometeorology $T_{\mathrm{mrt}}$ is usually calculated for a standardised standing person. Since measurements are not available on many operational meteorological stations, different models exist, ranging from simple empirical models to full radiative-transfer models, which allow modelling of radiant fluxes based on standard meteorological measurements.

\section{Metabolic rate}

Total energy production in a human in unit time, commonly expressed in biometeorological studies based on the total body surface of a human in $\mathrm{Wm}^{-2}$. The standard BS EN ISO 8996:2004 (British Standards Institution 2005b) outlines the method for the estimation of metabolic heat production.

\section{Meteotropism (and meteortropism)}

Changes in organisms correlated with changes in the atmosphere. The pool of atmospheric impacts on people and animals is extensive: biological outcomes have been linked to a large suite of weather variables and pollutant concentrations, e.g., Gonçalves et al. (2007).

\section{Minimum mortality temperature}

The daily temperature (average, maximum, or minimum) associated with the fewest number of temperature-related mortality events in a particular city. The minimum mortality temperature (MMT) is particularly relevant in locations that display the characteristic "J-curve", which shows that mortality rates usually decrease as temperatures increase up to a certain point (the MMT). When temperatures increase above the MMT, mortality rates begin to increase again.

\section{Mitigation}

With respect to mitigation of disaster risk and disaster, mitigation is defined by the IPCC (2012a) as "The lessening of the potential adverse impacts of physical hazards (including those that are human-induced) through actions that reduce hazard, exposure, and vulnerability." With respect to climate change, the IPCC (2012a) define mitigation as "A human intervention to reduce the sources or enhance the sinks of greenhouse gases."

Morbidity

Morbidity is defined by the US CDC (CDC 2013) as "Any departure, subjective or objective, from a state of physiological or psychological well-being". Morbidity may also refer to a count of the number of individuals afflicted by some illness or reduced health status, the affected proportion of a population, or the temporal extent of the prevalence of a given illness or disease (Porta 2008).

Mortality displacement / "harvesting"

Mortality displacement is a term used in the context of heatrelated mortality. Mortality displacement is a phenomenon where the heat principally affects individuals whose health is already compromised and who would have died shortly anyway, regardless of the weather. Estimates of mortality displacement are often calculated for defined heat wave periods that include "before", "during" and "after" the heat wave periods, lasting typically less than 2 months (Gosling et al. 2007; Le Tertre et al. 2006; Sartor et al. 1995). The effect of mortality displacement is usually calculated by dividing the mortality deficit (the number of "negative excess deaths" after the heat wave, i.e. the number of deaths below that expected after the heat wave ) by the total number of excess deaths during the heat wave (i.e. deaths above that expected during the heat wave ) and converting to a percentage. Estimates of mortality displacement calculated by this method include $15 \%$ during the Belgium 1994 heat wave (Sartor et al. 1995), $6 \%$ and $30 \%$ in Paris and Lille respectively during the 2003 European heat wave in France (Le Tertre et al. 2006), and $71 \%, 45 \%$ and $59 \%$ in Budapest, London and Sydney, during heat waves of 1991, 2003 and 2004, respectively (Gosling et al. 2007).

\section{Mortality rate}

According to the US CDC (2013), a mortality rate is "A measure of the frequency of occurrence of death in a defined population during a specified interval of time".

Munich energy balance model for individuals

The Munich energy balance model for individuals (MEMI) is an energy balance model of the human body based on the heat-balance equation for the human body (Matzarakis and Amelung 2008) and the two-node model 
of Gagge et al. (1972):

$\mathrm{M}+\mathrm{W}+N R+\mathrm{C}+\mathrm{E}_{\mathrm{D}}+\mathrm{E}_{R e}+\mathrm{E}_{S w}+S T=0$

where:

$M \quad$ is the metabolic rate (internal heat production)

$W \quad$ is physical heat production

NR is net radiation of the body

$C$ is convective heat flow

$E_{\mathrm{D}}$ is latent heat flow to evaporate water into water vapour diffusing through the skin (imperceptible perspiration)

$E_{\mathrm{Re}}$ is respiratory heat flow

$E_{\mathrm{Sw}}$ is heat flow due to evaporation of sweat

ST is a storage term.

The unit of all heat flows is Watt (Höppe 1999).

Using the meteorological parameters $T_{\mathrm{a}}$ (air temperature), $T_{\text {mrt }}$ (mean radiant temperature), VP (water vapour pressure), and $\mathrm{v}$ (wind speed), MEMI calculates the skin and core temperature of a standard person under light activity $(80 \mathrm{~W})$ by taking clothing insulation into account.

\section{Nanoparticles}

Microscopic objects that are comprised of two or three dimensions between 1-100 $\mathrm{nm}$ in size. Nanoparticles may display different physical properties (such as conductivity, solubility, etc.) than their larger bulk material counterparts. Nanoparticles have some beneficial medical applications, such as coating tumours to enhance MRI images or as a catalyst to break down volatile organic compounds in the air. On the other hand, ambient nanoparticles may cause unexpected reactions in biological organisms and have been linked with respiratory and cardiovascular disease in humans (Plummer et al. 2011; Schulte and Trout 2011).

New wind chill equivalent temperature index

NOAA's National Weather Service new Wind Chill Equivalent Temperature (WCET) index is based on a human face model and calculates the dangers from winter winds and temperatures below the freezing point (NOAA 2011). WCET is an apparent temperature index. WCET calculates wind speed at an average height of 5 feet, or $1.5 \mathrm{~m}$ (typical height of an adult human face) based on readings from the national standard height of $33 \mathrm{ft}$, or $10 \mathrm{~m}$ (typical height of an anemometer) and incorporates heat transfer theory, regarding heat loss from the body to its surroundings, during cold and breezy/ windy days. It uses a consistent standard for skin tissue resistance and assumes no impact from the sun (i.e. clear night sky) (Osczevski and Bluestein 2005). In a recent evaluation of the WCET, Shitzer and Tikuisis (2012) suggest to improve the reliability of the values predicted by the WCET by applying a

whole body thermoregulation model to evaluate human exposure to cold-windy conditions.

$\mathrm{NO}_{\mathrm{x}}$

An abbreviation commonly used to describe the combined local atmospheric concentration of the compounds nitric/ nitrous oxide $(\mathrm{NO})$ and nitrogen dioxide $\left(\mathrm{NO}_{2}\right) . \mathrm{NO}_{\mathrm{x}}$ is formed naturally in the atmosphere, especially at high altitudes, by the intense heat of lightning (Levine et al. 1984). Near the surface, $\mathrm{NO}_{\mathrm{x}}$ is formed largely by combustion (automobiles, industry, etc.), microbial activity in soils, and widespread application of nitrogen-rich, agricultural fertiliser (Harrison et al. 1995; Shepherd et al. 1991; Zhang et al. 2012). The reaction of $\mathrm{NO}_{\mathrm{x}}$, particularly $\mathrm{NO}_{2}$, with other anthropogenic chemicals contributes to the formation of tropospheric ozone $\left(\mathrm{O}_{3}\right)$. In the stratosphere, $\mathrm{NO}_{\mathrm{x}}$ has been shown to reduce ozone $\left(\mathrm{O}_{3}\right)$ concentrations and most of this $\mathrm{NO}_{\mathrm{x}}$ is a result of $\mathrm{N}_{2} \mathrm{O}$ emissions (Revell et al. 2012). $\mathrm{NO}_{2}$, specifically, has been shown to have negative effects on the human respiratory system (Chauhan et al. 1998).

\section{Odds ratio}

A comparison of the probability of one outcome given a circumstance to that of a separate outcome given a separate circumstance. In a classical example, an odds ratio compares binary disease outcomes to binary exposures. To calculate an odds ratio one would use a $2 \times 2$ contingency table (see Table 3 ) summarising the frequency of observations for each group in the presence and absence of an exposure. The odds from Group 1 are $a / b$, and the odds for Group 2 are $c / d$. The odds ratio is a comparison of the two, which simplifies to ad/bc. An odds ratio of one implies that the event is equally likely for both groups; greater than one implies that the event is more likely in the first group; less than one implies higher likelihood in the second group.

\section{Operative temperature}

In a black enclosure, the uniform temperature at which a human occupant would exchange the same amount of heat by radiation and convection as in the actual non-uniform environment (British Standards Institution 2002b; IUPS Thermal Commission 2001). The optimum temperature

Table 3 An example $2 \times$ 2 contingency table for calculating an odds ratio

\begin{tabular}{lll}
\hline & Event $(+)$ & No event (-) \\
\hline Group 1 & $\mathrm{a}$ & $\mathrm{b}$ \\
Group 2 & $\mathrm{c}$ & $\mathrm{d}$
\end{tabular}


corresponds to a predicted mean vote (PMV) of 0 , and is dependent on clothing and activity.

\section{Outdoor air quality}

An evaluation of the atmospheric constituents present in a given environment versus those present in pure air. Formal descriptions generally report the quantity of additions to pure air (WHO 2006). These additions can be of solid and gaseous state, and can be of natural or artificial origin. They can show positive or adverse effects on health: the smaller solid particles are, the deeper they can enter the lung.

\section{Ozone}

A molecule consisting of three oxygen atoms $\left(\mathrm{O}_{3}\right)$. Most of the Earth's ozone is in the stratosphere in what is often referred to as "the ozone layer". Ozone is created by the interaction of diatomic oxygen $\left(\mathrm{O}_{2}\right)$ with ultraviolet (UV) radiation. UV radiation splits $\mathrm{O}_{2}$ into two separate oxygen atoms that then react with another $\mathrm{O}_{2}$ molecule to form $\mathrm{O}_{3}$. Beginning in the late 1970s, scientists observed that stratospheric ozone concentrations were depleted, determined to be a result of the reaction of stratospheric ozone with industrial halogens such as CFCs and other artificial compounds. Since the ozone layer absorbs some bands of solar UV radiation, the most direct threat to human health from this depletion is an increase in skin cancers. The lowest levels of stratospheric ozone occurred in 1992-1993. Stratospheric ozone levels are now increasing, in part due to the 1987 Montreal Protocol and subsequent reductions of CFCs. Full regeneration of the ozone layer will take several decades. At ground level, ozone is formed by chemical reactions between nitrogen oxides $\left(\mathrm{NO}_{\mathrm{x}}\right)$ and volatile organic compounds (VOCs) in the presence of sunlight. Ozone in the troposphere is considered a secondary pollutant. Commonly cited negative impacts of tropospheric ozone include distress to the human respiratory system and decreased visibility, particularly in urban areas (Armstrong 1994; UN Environment Program 1998).

Pandemic

Observation of an unusually high occurrence of cases of a certain disease spreading through human populations across a large region; for instance multiple continents, or even worldwide (Porta 2008).

\section{Perceived temperature}

Perceived temperature (PT) is a human biometeorological parameter that describes the thermal perception of an individual, by the use of the air temperature of a reference environment (Staiger et al. 2011). This environment is defined as an indoor room, with the wind velocity reduced to a slight draught, a mean radiant temperature that equals the air temperature, and a water vapour pressure of $50 \%$. The thermo-physiological modelling is based on the Klima Michel model (KMM).

Phenoclimatology

Integration of phenological observations with climate data toward the goal of producing models and assessments of changes in the start and end of the growing season at continental-scales (Rötzer et al. 2004; Schwartz 2003; Schwartz et al. 2006).

\section{Phenology}

As defined by the USA-NPN (National Phenology Network) (2013): "Phenology refers to recurring plant and animal life cycle stages. It is also the study of these recurring plant and animal life cycle stages, especially their timing and relationships with weather and climate."

Phenological event

As defined by the USA-NPN (2013): "A precisely defined point in the life cycle of a plant or animal, generally marking the start or end point of a phenophase. The occurrence of a phenological event can be pinpointed to a single date and time (in theory, if not in practice). Examples include the opening of the first flower on a plant, the end of leaf fall on a tree, the first appearance of a particular songbird species in spring, or the start of fish migration up-river to spawn."

Phenological shift (or phenological change)

The change of averaged timing of phenological events of organisms over time periods often measured by years or decades; often used as biological indicators of climate change (Cleland et al. 2007; Parmesan and Yohe 2003).

Phenological stage

See "Phenological event".

Phenological status

As defined by the USA-NPN (2013): "The state of one or more phenophases for an individual or species at a given moment (Harris and Harris 1997). Phenological status could include but is not limited to measures of the state of flowers, leaves, and fruits for plants or migration, breeding, and development for animals. For example, the phenological status of a plant might be: has flowers and unfolded leaves; does not have 
ripe fruits. For birds, an example might be: is present, is an adult, and is calling; is not building or sitting on a nest."

\section{Phenophase}

As defined by the USA-NPN (2013): "An observable stage or phase in the annual life cycle of a plant or animal that can be defined by a start and end point. Phenophases generally have duration of a few days or weeks. Examples include the period over which newly emerging leaves are visible, or the period over which open flowers are present on a plant." It should be noted that the definition of the term "phenophase" has not yet been standardised and varies among scientists - the definition presented here is that adopted by the USA-NPN.

\section{PHEWE project}

The PHEWE (assessment and prevention of acute health effects of weather conditions in Europe) project (Michelozzi et al. 2004) applied a standardised scientific approach to provide better knowledge on the human health effect of hot and cold atmospheric temperature and on the role of several effect modifiers. The general aim of the project was to assess the acute health effects of extreme weather, during the winter and summer season, in 16 European cities characterised by different climatic conditions, and to propose preventive strategies to reduce the health impact of weather conditions. The project lasted for 44 months between 2002 and 2006 and it was funded by the EU Fifth Framework Program.

\section{Physiological equivalent temperature}

Physiological equivalent temperature (PET) is a human biometeorological parameter that describes the thermal perception of an individual. It is defined as the air temperature at which, in a typical indoor setting (without wind and solar radiation), the heat budget of the human body is balanced with the same core and skin temperature as under the complex outdoor conditions to be assessed (Höppe 1999). The typical indoor setting is an indoor room, with windspeed $(\mathrm{v})=$ $0.1 \mathrm{~ms}^{-1}$, vapour pressure $(\mathrm{VP})=12 \mathrm{hPa}$ and mean radiant temperature $\left(T_{\text {mrt }}\right)$ equal to the air temperature $\left(T_{\mathrm{a}}\right)$. For calculating the physiological parameters PET makes use of the Munich energy balance model for individuals (MEMI).

\section{Phytophenology}

Or plant phenology, the science of relating microclimate to periodic events in plant life (Defila and Clot 2001).
Planetary boundary layer

The bottom layer of the troposphere that is in contact with the surface of the Earth (AMS 2013)—-see Fig. 2. The planetary boundary layer (PBL) is sometimes also called the atmospheric boundary layer. The depth of the PBL varies in time and space (ranging from tens of metres to several kilometres).

$\mathrm{PM}_{2.5}$

$\mathrm{PM}_{2.5}$ (where $\mathrm{PM}$ is "particulate matter") refers to particles with an aerodynamic diameter less than $2.5 \mu \mathrm{m}$. Unlike $\mathrm{PM}_{10}$, these particles can penetrate into the gas exchange regions of the lung and deposit in the alveoli (WHO 2006). A large number of particles in this fraction are formed from gases and combustion processes.

$\mathrm{PM}_{10}$

$\mathrm{PM}_{10}$ (where $\mathrm{PM}$ is "particulate matter") refers to particles with an aerodynamic diameter less than $10 \mu \mathrm{m}$. These particles can penetrate the human respiratory system down to the lower thoracic region and cause serious health impacts (WHO 2006). $\mathrm{PM}_{10}$ is produced mainly mechanically by the breakdown of larger solid particles and by biological sources. Highest $\mathrm{PM}_{10}$ concentrations can be measured in regions with high traffic and heavy industry (Kappos et al. 2004). PM $\left(\mathrm{PM}_{10}\right.$ as well as $\mathrm{PM}_{2.5}$ and $\left.\mathrm{PM}_{1}\right)$ is known to cause different health effects, mainly in the respiratory systems. In light of the negative health effects arising from particulates, many countries have defined measures to reduce PM emissions and increase air quality, e.g. by defining threshold values.

$\mathrm{PM}_{1}$ and ultra-fine particles

$\mathrm{PM}_{1}$ (where PM is "particulate matter") and ultra-fine particles are those with an aerodynamic diameter less than $1 \mu \mathrm{m}$ $\left(\mathrm{PM}_{1}\right)$ or $0.1 \mu \mathrm{m}$ (ultra-fine particles), respectively. These particles originate mainly from high-temperature combustion processes (WHO 2006). Due to their small diameter, measurement of these particles is complex, and the number of available long-time measurements is much smaller than for PM2.5 or PM10. Therefore, the health effect of ultrafine particles is less well known (Kappos et al. 2004; WHO 2003).

\section{Poisson regression}

A statistical model that relates the values of one or more independent values to those of a dependent variable, where the dependent variable is represented by count data. The assumption of a Poisson regression model is that the count data in a particular unit of time follows the Poisson distribution (Loomis et al. 2005). 

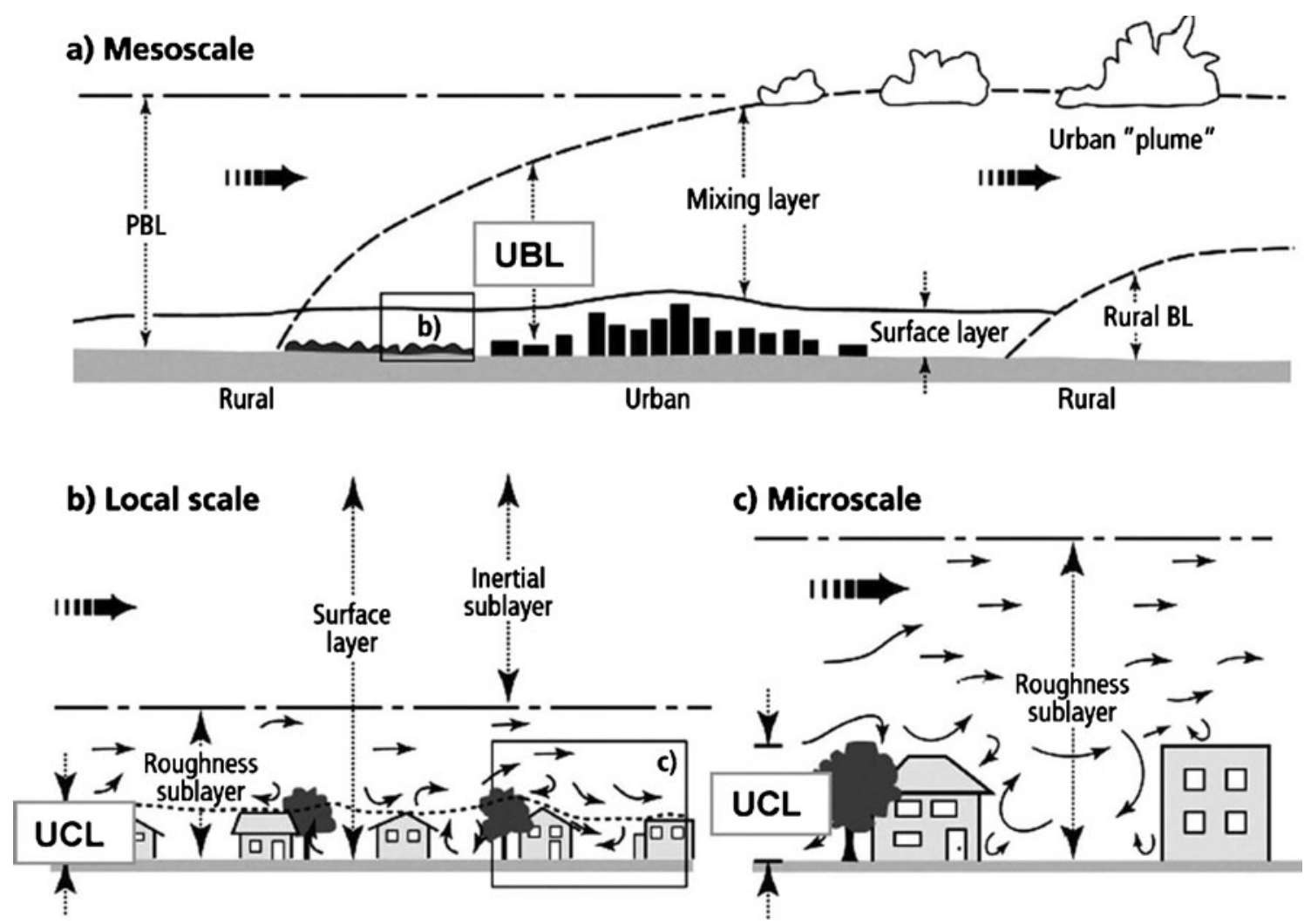

Fig. 2a-c Schematic of the urban boundary layer (UBL) including its vertical layers and scales. UCL Urban canopy payer; $P B L$ planetary boundary layer. Vertical dotted arrows denote the spatial extent of each

\section{Pollen}

Pollen grains are microscopic containers $(10-100 \mu \mathrm{m})$ of male gametes of flowering plants (phanerogams) (Campbell 1996). They consist of very hard material in a wide variety of characteristic shapes according to species. The transfer of pollen grains to the female reproductive structure (pollination) can be mediated by the wind (anemophily) or by insects (entomophily).

Pollen calendar

A phenological table showing onset, duration, and end of pollen production of different species during the seasons. It varies for individual regions across the world. It is a component part of many advance warning systems for persons allergic to pollen (see allergenic pollen), which are provided layer. Solid arrows denote direction of air flow. Modified from Oke (1997) and reproduced from Marshall (2004). a Mesoscale, b local scale, c microscale

by numerous meteorological agencies (Oh et al. 2012). An example for central Europe is presented in Fig. 3.

Potential evapotranspiration

Potential evapotranspiration is the amount of evaporation and transpiration that occurs over the land's surface, or would occur if the water supply were unrestricted (Davie 2008). Potential evapotranspiration can be calculated by different methods. The most common methods include those of Thornthwaite (1944), Penman (1948) and Penman-Monteith (Monteith 1965). Importantly, recent studies have demonstrated a high sensitivity of simulated river runoff to the method of potential evapotranspiration calculation applied by various hydrological models (Gosling and Arnell 2011; Kingston et al. 2009).

\begin{tabular}{|c|c|c|c|c|c|c|c|c|c|}
\hline & Jan & Feb & Mar & Apr & May & Jun & Jul & Aug & Sep \\
\hline Hazel & & & & & & & & & \\
\hline Alder & & & & & & & & & \\
\hline Birch & & & & & & & & & \\
\hline Grasses & & & & & & & & \\
\hline Herbs & & & & & & & & & \\
\hline
\end{tabular}

Fig. 3 A typical pollen calendar for central Europe. Lightest shading denotes the range of pollen release (start and end) and darker shading denotes peak periods (the darker the shading, the greater the pollen concentrations) 
Table 4 American Society of Heating, Refrigerating, and Air-Conditioning Engineers (ASHRAE) thermal sensation scale

\begin{tabular}{ll}
\hline Value & Sensation \\
\hline-3 & Cold \\
-2 & Cool \\
-1 & Slightly cool \\
0 & Neutral \\
+1 & Slightly warm \\
+2 & Warm \\
+3 & Hot \\
\hline
\end{tabular}

Predicted mean vote

An index used to predict the mean response of a large group of people, exposed to the same ambient conditions, according to the ASHRAE (American Society of Heating, Refrigerating, and Air-Conditioning Engineers) thermal sensation scale (Table 4).

PMV was originally calculated by Fanger (1972) using the equation:

$P M V=\left(0.303 \mathrm{e}^{-0.036 \mathrm{M}}+0.028\right) \mathrm{L}$

where:

$\mathrm{M}$ is metabolic rate

$\mathrm{L}$ is thermal load.

Fanger (1967) also developed a related index, called the predicted percentage dissatisfied (PPD), which is calculated from PMV, and predicts the percentage of people who are likely to be dissatisfied with a given thermal environment. BS EN ISO 7730:2005 (British Standards Institution 2006) uses both the PMV and PPD.

\section{Predicted percent dissatisfied}

Developed by Fanger (1967), the predicted percent dissatisfied (PPD) is an index that predicts the percentage of thermally dissatisfied people who feel too cool or too warm, and is calculated from the predicted mean vote (PMV). The PMV and PPD form are therefore closely related, and both indices take the form of a U-shaped relationship, where percentage dissatisfied increases for PMV values above and below zero (thermally neutral). At the neutral temperature as defined by the PMV index, PPD indicates that $5 \%$ of occupants will still be dissatisfied with the thermal environment. The standard BS EN ISO 7730:2005 (British Standards Institution 2006) uses both the PPD and PMV.

Prevalence

The proportion of occurrence of a particular health outcome within a given population, usually expressed as the number of impacted individuals divided by the total population (or an atrisk population) (Porta 2008).

Radiant heat exchange

Heat transfer per unit area $\left(\mathrm{Wm}^{-2}\right)$ by the exchange of thermal radiation between the ambient environment and the human body. Based on four components of radiant energy: incoming shortwave radiation, reflected shortwave radiation, incoming longwave radiation, and emitted longwave radiation. A positive value indicates heat transfer to the environment; negative indicates heat absorption by the body (IUPS Thermal Commission 2001).

Reference crop evaporation

The rate of evapotranspiration from a hypothetical reference crop. Two main crops are sometimes used as the reference crop: ryegrass (Lolium perenne L.) or alta fescue (Festuca arundinacea Schreb. Alta). Reference crop evaporation is defined by the AMS (2013) as: "The quantity of water evaporated per unit area, per unit time from a continuous, uniform area of grass with a fixed height of $0.12 \mathrm{~m}$, an albedo of 0.23 , and a surface resistance of $69 \mathrm{~s} \mathrm{~m}^{-1}$; approximated by the rate of evaporation for an extensive area of 0.08 to $0.15 \mathrm{~m}$ high green grass cover of uniform height, actively growing, completely shading the ground, and not short of water."

Relative air velocity

Considers the combined effects of wind speed, activity speed (speed at which an individual is moving), and the degree angle $(\alpha)$ between the wind direction and body movement for estimation of free and forced convective heat transfer due to wind (Vanos et al. 2012). Facing the wind, the relative air velocity $\left(v_{\mathrm{r}}\right)$ is the sum of the walking velocity and air velocity. With the wind at back, the relative air velocity is the absolute value of the difference between walking and wind speeds (British Standards Institution 2009a). For all other angles, the relative air velocity may be calculated as follows (British Standards Institution 2009a; Havenith et al. 2012; Vanos et al. 2012):

$v_{r}=\sqrt{\left[\left(v_{w}-v\right) \cos (\alpha)\right]^{2}+[v \sin (\alpha)]^{2}}$

where:

$v \quad$ is the wind speed $\left(\mathrm{m} \mathrm{s}^{-1}\right)$

$v_{\mathrm{w}}$ is the walking speed $\left(\mathrm{m} \mathrm{s}^{-1}\right)$

$\alpha \quad$ is the angle between walking and air directions $\left(0^{\circ}\right.$ if both are in the same direction).

Relative air velocity can influence the predicted mean vote (PMV) and predicted percent dissatisfied (PPD) indices as the 
convective and evaporative heat exchanges are influenced by relative air velocity, and local thermal discomfort can occur due to draught of air velocity (British Standards Institution 2002b). To this end, relative air velocity is relevant to the standard BS EN ISO 7730:2005 (British Standards Institution 2006).

\section{Required evaporative heat loss}

Required evaporative heat loss $\left(\mathrm{E}_{\text {req }}\right)$ is the evaporation that is required by the body to maintain a thermal balance. Represented by the sum of the net metabolic heat production by the human body, and exchanges of radiation and convection (Brotherhood 2008). Hence, to maintain energy balance, the sum of these components must equal evaporative cooling.

\section{Risk factor}

A characteristic of an individual or an element of their environment or behaviours that is associated with an elevated probability of contracting a certain disease or condition based on scientific evidence (Porta 2008). For example, smoking is considered a risk factor for contracting lung cancer.

\section{Root carbon storage}

Carbon stored in the soil forms a major carbon store of the terrestrial biosphere, which consists of soil organic matter, plant litter and living biomass in the form of plant roots (Kleidon and Heimann 1996). This gives rise to the term "root carbon storage". The amount of carbon stored in the soil of temperate and boreal forests is about four times higher than that stored in the above-ground vegetation, and $33 \%$ higher than total carbon storage in tropical forests (Watson et al. 2000). A recent study showed that although carbon dioxide enrichment can cause short-term growth stimulation in some tree species, it also leads to an increase in soil microbial respiration and a marked decline in sequestration of root-derived carbon in the soil (Heath et al. 2005). The study concluded that if similar processes operate in entire forest ecosystems, the size of the annual terrestrial carbon sink may be substantially reduced, resulting in a positive feedback on the rate of increase in atmospheric carbon dioxide concentration.

\section{Roughness sub-layer}

Roughness sub-layer (RSL) corresponds to the air layers immediately above horizontally uniform surface types with tall roughness elements, where conventional fluxprofile relationships and Monin-Obukhov similarity theory are likely to be invalid. In this layer flow consists of the interacting wakes and plumes (of heat, humidity and pollutants) introduced by individual roughness elements (Raupach 1979). The nature of the urban surface, with its rigid buildings of different heights and physical characteristics, separated by trees, urban canyons and open spaces, makes it particularly susceptible to the development of a RSL of significant depth, perhaps several times the average building height (Arnfield 2003; Roth 2000). Figure 2 displays a schematic of the urban boundary layer (UBL) including its vertical layers and scales.

\section{Seasonality (in phenology)}

Periodical non-biological events, such as timing of the fall formation and spring break-up of ice on fresh water lakes (Magnuson et al. 2000; Schwartz 2003).

\section{Selection for adaptation index of beef cattle}

It is known that the productive performance of animals is related to their adaptation to the environment in which they live. Silva (1973) proposed a simultaneous selection for yield and adaptation in existing cattle in tropical regions, based on genetic and phenotypic relationships between characters of production and those associated with adaptation. The higher the value of the selection for adaptation index of beef cattle (SI), the greater the merit of the animal for breeding, since this value estimates the additive genetic merit. The index was calibrated from data on bulls 18 months of age, placed in a corral, fully exposed to the sun on a summer day, between 0900 hours and 1500 hours, and measuring the rectal temperature and respiratory rate at these two times. The index is calculated as:

$S I=100-0.26 \mathrm{X}_{1}-0.064 X_{2}-0.009 \mathrm{X}_{3}-0.133 \mathrm{X}_{4}+0.281 \mathrm{X}_{5}$

where:

$X_{1} \quad$ is the rectal temperature in the morning

$X_{2}$ is the increase in rectal temperature between the two times

$X_{3}$ is the respiratory rate in the morning

$X_{4}$ is the decimal logarithm of the increase in the respiratory rate between the two times

$X_{5}$ is the average daily weight gain between weaning and 18 months of age.

\section{Senescence}

The gradual deterioration of physiological function in biological organisms over time, commonly associated with reduced reproduction rates and increased mortality risk (Ricklefs and Miller 1999). 
Sensible heat flux in animals

Sensible heat fluxes can occur from an animal to the surrounding environment and vice versa. This occurs due to a gradient of temperature between the body surface of the animal and the environment. The equations and models used for its determination were described by McArthur (1987) and adopted by Maia et al. (2005).

\section{Sick building syndrome}

A group of mucosal, skin, and general symptoms that are temporally related to working in particular buildings (Burge 2004). A recent review (Norbäck 2009) showed that sick building syndrome (SBS) is related to both personal and environmental factors, with increasing evidence for the role of personality traits and psychosocial work environment, reactive chemistry and the inflammatory properties of indoor particles for SBS. The review also noted that the link between indoor and outdoor air pollution should not be neglected when assessing SBS (Norbäck 2009).

\section{Skill score}

A numerical measure of the overall success of a model or group of forecasts compared to a background or reference. The score is often expressed in terms of percentage improvement over the reference. Although skill scores often offer a more complete assessment of performance than simpler measures including percent correct and false alarm rate, no score can perfectly represent a model's or forecast's strengths and weaknesses. Examples of skill scores for binary forecast/ observation data arranged into a 2-by-2 contingency table include the Heidke Skill Score, Pierce Skill Score, and Yule's $Q$ (Wilks 1995).

Skin characteristics and climate (in animals)

The skin characteristics of an animal changes according to the climate in which it is located. The skin surface, consisting of the epidermis and its appendages (hair, wool, sweat glands and sebaceous glands in mammals, birds feathers and down; corneas structures in reptiles), represents the most extensive line of contact between the organism and environment. This condition determines the characteristics of the external body surface, depending on the characteristics of the environment and nature of the organism to which it belongs. Thus, animals that live in extremely dry deserts and places must have extra protection against water loss and intense solar radiation. Those that are characteristic of cold regions require a barrier against loss of body heat. Finally, there are those who live in regions climatically unstable, where extreme cold may alternate with extreme heat. Animals here must have external characteristics appropriate for compensating for changes in climate (Da Silva and Maia 2013).

Sky view factor $\left(\Psi_{\text {sky }}, \mathrm{SVF}\right)$

A measure of the amount of sky that is visible from a given point. Sky view factors (SVFs) are determined using either geometry (width, height, etc.) or photographs taken with a fish-eye lens. They are expressed as a percentage, with $100 \%$ being a fully visible sky (i.e. the two dimensional surface of the hemisphere above) and $0 \%$ being a sky that is fully obstructed.

\section{Soil organic matter}

Residual material from biological organisms on and below the ground surface, e.g., leaf litter (Brady and Weil 2002). It has complex chemical composition with different degrees of microbial decomposition. The quality and quantity of soil organic matter is closely connected to the interactions of vegetation, soil, and climate.

\section{Spatial regression}

A set of statistical techniques that considers topological or geographical information in a regression analysis. The spatial properties of the data can be used as: independent or dependent variables: a relationship between dependent variables; in the error terms; weights in a weighted regression; or as a spatial lag.

\section{Spring indices}

Continental-scale models of the onset of the spring season, most applicable to trees and shrubs in non-moisture limited temperate climates (Schwartz et al. 2006).

Steadman apparent temperature index

Not one, but several apparent temperature indices calculated by Steadman (1979a, 1979b, 1984). In an attempt to quantify "sultriness", Steadman (1979a, b) incorporated temperature, humidity, clothing and human physiology into a number of algorithms, which were later simplified into regression equations for indoor, shaded and sunny conditions (Steadman 1984). The regression equations were later adapted by Rothfusz (1990) to create the heat index (HI).

Stomatal conductance

The rate at which vapour (usually water vapour or carbon dioxide) is transported between the plant and atmosphere, due to a vapour pressure gradient, through the stomata. 
The inverse value, stomatal resistance, is sometimes conveyed.

\section{Stomatal resistance}

The resistance of water vapour flow for an individual leaf, dependent upon the amount of water available to the plant, the aperture of the stomata and the density of stomata (FAO 2013).

\section{Surface resistance}

The resistance of vapour flow through a transpiring crop and evaporating soil surface (FAO 2013).

Synoptic classification/air mass

An air mass is a large volume of air with homogeneous characteristics, especially with respect to temperature and moisture. Synoptic classification systems aim to discretise daily weather into subsets with similar regional-scale meteorology, and are commonly based on temperature or pressure fields at the surface (Kalkstein et al. 1996; Sheridan 2002). In recent years the terms have become more interchangeably used in the literature, as many classification systems aim to identify particular air mass types. Some investigators develop classification systems for particular applications (Kalkstein et al. 2011), while others adopt automated classifications available for certain geographies.

Temperature humidity index

Originally described by Thom (1959) for humans, this thermal comfort index is also widely used as a heat stress indicator for animals. There are several equations that can be used to calculate the temperature humidity index (THI) and these were compared by Bohmanova et al. (2007). They are listed below with details of their application (Bohmanova et al. 2007).

1. To monitor discomfort from temperature and humidity in humans (Bianca 1962):

$$
T H I=1.8\left(0.15 \mathrm{~T}_{\mathrm{a}}+0.85 \mathrm{~T}_{\mathrm{w}}\right)+32
$$

2. Empirically determined in cattle exposed to heat stress conditions in climatic chambers (Bianca 1962):

$T H I=1.8\left(0.35 \mathrm{~T}_{\mathrm{a}}+0.65 \mathrm{~T}_{\mathrm{w}}\right)+32$

3. To monitor the degree of discomfort in humans (Thom 1959):

$$
T H I=1.8\left(0.4\left(\mathrm{~T}_{\mathrm{a}}+\mathrm{T}_{\mathrm{w}}\right)\right)+32+15
$$

4. The Oklahoma Mesonet Cattle Heat Stress Index, which is designed to indicate the level of heat stress of outdoor cattle (National Research Council 1971):

$$
T H I=\left(1.8 \mathrm{~T}_{\mathrm{a}}+32\right)-(0.55-0.0055 \mathrm{R}) \times\left(1.8 \times \mathrm{T}_{\mathrm{a}}-26\right)
$$

5. Developed by the United States Weather Bureau to describe discomfort in humans (National Research Council 1971):

$$
T H I=0.72\left(\mathrm{~T}_{\mathrm{a}}+\mathrm{T}_{\mathrm{w}}\right)+40.6
$$

6. Empirically determined in cattle exposed to heat stress conditions in climatic chambers (Yousef 1985):

$T H I=\mathrm{T}_{\mathrm{a}}+0.36 \mathrm{~T}_{\mathrm{d}}+41.2$

Where:

$T_{\mathrm{a}} \quad$ is the dry bulb temperature (also known commonly as the air temperature) $\left({ }^{\circ} \mathrm{C}\right)$

$T_{\mathrm{w}} \quad$ is the wet bulb temperature $\left({ }^{\circ} \mathrm{C}\right)$

$T_{\mathrm{d}} \quad$ is the dew point temperature $\left({ }^{\circ} \mathrm{C}\right)$

$R \quad$ is the relative humidity (\%).

\section{Thermal comfort}

Thermal comfort is the condition of mind that expresses satisfaction with the thermal environment; however, due to large physiological and psychological variations from one person to another, it is difficult to maintain thermal comfort in one given space for all (ASHRAE 2004), whether it be indoors or outdoors. It is crucial for human beings to maintain a constant core body temperature of $37^{\circ} \mathrm{C}\left(98^{\circ} \mathrm{F}\right)$. However, the temperature away from the core, such as on the skin and extremities for instance, can vary considerably with environmental and metabolic heat loads. To maintain the core body temperature, heat is exchanged with the environment by respiration (latent and sensible heat fluxes), radiation (longwave and shortwave), evaporation (latent heat flux), conduction (contact with solids), and convection (sensible heat flux) (Jendritzky and de Dear 2009). To this end, the human thermoregulatory system can be separated into active and passive interacting systems. The active system concerns the thermoregulatory response (e.g. shivering or perspiring) and the passive system deals with heat transfers at the body surface. When the body is under thermal comfort conditions, the body is under least strain because the active system is at its lowest activity level. However, increasing discomfort is associated with increasing strain. Research shows that people take action to improve their comfort conditions by modifying their clothing and metabolic rate when outdoors, or by interacting with the building when they are indoors, which are considered 
actions of adaptation (Nicol and Humphreys 2002). When adaptation opportunity is limited, departure from neutrality causes stress and dissatisfaction (Baker and Standeven 1996). According to Nikolopoulou et al. (2001), intrinsic factors such as past experience, expectations and time of exposure are also important for thermal comfort.

\section{Thermal comfort index for sheep}

The thermal comfort index for sheep (TCIS) was introduced by Silva and Barbosa (1993) and it was developed specifically for the classification of environments for sheep farming. It is calculated as:

TCIS $=0.659 \mathrm{~T}_{\mathrm{a}}+0.511 V P+0.550 \mathrm{~T}_{\mathrm{g}}-0.042 \mathrm{v}$

where:

$T_{\mathrm{a}} \quad$ is the air temperature $\left({ }^{\circ} \mathrm{C}\right)$

VP is the vapor pressure $(\mathrm{kPa})$

$T_{\mathrm{g}} \quad$ is the black globe temperature $\left({ }^{\circ} \mathrm{C}\right)$

$v \quad$ is the wind speed $\left(\mathrm{ms}^{-1}\right)$.

\section{Thermal discomfort}

Thermal discomfort can be caused by unwanted local cooling or heating of the body due to radiant temperature asymmetry (cold or warm surfaces), draught (defined as a local cooling of the body caused by air movement), vertical air temperature difference, and cold or warm floors (British Standards Institution 2002b). It can be used to calculate the predicted percent dissatisfied (PPD).

\section{Thermal stress}

In hot environments and/or during increased physical activity, the body may not be able to effectively dissipate metabolic heat. This situation can ultimately lead to increased core body temperature and diminished physical and mental abilities. Heat exhaustion and heat stroke are also possible side effects of sustained elevated body temperature. In extreme cases thermal stress can directly lead to human mortality. There are numerous quantitative indices for assessing potential thermal stress, including the Heat Stress Index (HSI), the Wet Bulb Globe Temperature (WBGT), the Index of Heat Stress, the Physiological Equivalent Temperature (PET), the Universal Thermal Climate Index (UTCI) and the Humidex.

Thermal time

See "Growing degree-day".
Thermoregulation

Thermoregulation is the process of thermal energy control in any physical system (Da Silva and Maia 2013). Living organisms produce energy by metabolic processes and gain and lose energy from the environment. When there is no change in the metabolic heat production or any evaporative heat loss, it is possible to define the thermoneutral zone, limited by the lower critical temperature and the upper critical temperature. Here, the organism does not need to gain or lose energy to the environment. In the zone of homeothermy, the organism can maintain its body temperature within narrow limits.

\section{Thermotolerance}

Thermotolerance is "the ability of a cell or an organism to become resistant to heat stress" (Kregel 2002).

Threshold temperature

Temperature above or below at which significant elevations in morbidity or mortality are observed. In the case of heat-related mortality, methods for establishment of threshold temperatures include identification of an inflection point in the "Jshaped" or "U-shaped" relationship between temperature and mortality (Gosling et al. 2007), or a certain percentile of temperature associated with statistically significant increases in risk of mortality (Basu 2009). Threshold temperatures systematically vary geographically, such that those regularly exposed to high temperatures are less susceptible to heat than those that live in cooler locales (e.g. Davis et al. 2002).

Time-series analysis

A method for analysing data typically measured at successive times spaced at uniform intervals. Examples of time series are observations of weather and health indicators (Hajat et al. 2002) or crop production (Simelton et al. 2012). Its aim is to determine the pattern of progression by constructing a model. The simplest approach (descriptive-deterministic) considers the general direction of long-term development (trend), a cyclic drive within a certain time (e.g. seasonality) and an irregular component, that contains outliers or random fluctuation. By describing observations, regularity and changes can be detected and future developments estimated and forecast.

Town energy balance

A model developed by Masson (2000) to explain the turbulent flux interaction between the atmosphere and urban areas. The town energy balance (TEB) scheme uses urban canyon geography (a road lined by tall buildings). The model mimics the effect of buildings by finding a specific energy balance for 
three surface types: roof, wall, and road. The inputs are geometric, radiative and thermal parameters of the urban surface. The model output includes turbulent heat flux, outgoing longwave radiation, and outgoing shortwave radiation.

\section{Tourism climate index}

One of a suite of measures that aim to capture the relative appeal of different potential destinations for vacation and recreation. These measures are based largely on the weather and climate of a particular locale, and some include estimates of the energy balance to assess thermal comfort (Lin and Matzarakis 2008). The tourism climate index (TCI) of Mieczkowski (1985) includes measures of temperature, relative humidity, monthly rainfall, hours of sunshine, and wind speed. Recently developed climate indices, including the climate index for tourism (CIT) (de Freitas et al. 2008), incorporate a larger suite of variables to assess physiological stress and/or empirical data gleaned from visitors to various locales.

$t$-Test

A $t$-test compares the means of two respective samples of data to suggest whether both samples come from the same population. If a given sample is compared with a known mean, then a single sample $t$-test is applied. If two samples need to be compared, and the samples were collected independently, then an independent sample $t$-test is applied. When two samples are not independent of each other and have some factor in common, the paired sample $t$-test can be applied. The test may also be used to compare linear regression slopes or correlation coefficients for significant differences.

\section{Universal thermal climate index}

The universal thermal climate index (UTCI) is an international standard performed by the European Cooperation in Science and Technology (COST) Action 730, based on recent research in human response-related thermo-physiological modelling (COST 2011). For any combination of air temperature, wind, radiation, and humidity (stress), UTCI is defined as the isothermal air temperature of the reference condition that would elicit the same dynamic response (strain) of the physiological model (Jendritzky et al. 2012). The associated assessment scale is developed from the simulated physiological responses and comprises ten categories: extreme cold stress; very strong cold stress; strong cold stress; moderate cold stress; slight cold stress; no thermal stress; moderate heat stress; strong heat stress; very strong heat stress; and extreme heat stress ("stress" refers to the physiological workload to maintain thermal equilibrium) (Błażejczyk et al. 2013). The International Journal of Biometeorology published a Special Issue for the UTCI in
2012 (McGregor 2012a). UTCI is an apparent temperature index.

Urban boundary layer

The urban boundary layer (UBL) is that portion of the planetary boundary layer (PBL) above the urban canopy layer (UCL) whose climatic characteristics are modified by the presence of a city at the surface (Oke 1976) (see Fig. 2). The UBL derives its characteristics from exchanges at its lower "surface", a loosely defined interface located at roof level; the interface can be treated as a rough, flat, surface with generalised roughness, thermal and radiative characteristics (Arnfield 2003; Mills 1997).

Urban canopy layer

The urban canopy layer (UCL) is the layer in the vertical structure of the urban boundary layer (UBL) ranging from the surface to the top of buildings (Oke 1976; Roth 2000) (see Fig. 2). Within the UCL, the urban local scale climate is influenced greatly by the thermal properties of buildings and surfaces as well as local-scale flows arising from the geometry of buildings and streets (Oke 1987).

\section{Urban canyon}

Open-air spaces between buildings in metropolitan areas that are located above streets, sidewalks, and alleys. Air movement through the city is controlled largely by the geometry of the open spaces, and the shapes of buildings and intersections create flows that significantly differ from the mean regional wind. The thermal climate of the urban canyon is impacted by the structural composition and shape of the buildings that surround it, especially their height and spacing in determining the patterns of sunlight and shading within the canyon (Oke 1987).

\section{Urban climate zones}

Discretisation of areas of the built environment based on the potential impact of buildings and other structures to modify the local atmosphere/environment. Urban climate zone (UCZ) classes are ranked approximately in order of their ability to modify the wind, thermal and moisture characteristics. These incorporate groups of Ellefsen's zones (Ellefsen 1991), plus a simple measure of the urban structure, which has been shown to be closely related to flow, solar shading and the nocturnal heat island. Also included is a measure of the surface cover $(\%$ built) that is related to the degree of surface permeability (or an inverse measure using \% open and vegetated; however, this does not increase with urban development as in the \% built version) (Oke 2004). This classification has been detailed and 
improved by Stewart and Oke throughout the LCZ model (local climate zones) inheriting from Oke's classification (Stewart and Oke 2009a, b; Stewart 2010).

\section{Urban heat island}

Increased temperature associated with a built environment, such as a city or town, with respect to near rural areas. The magnitude of the urban heat island (UHI) is typically higher at night, under clear and calm skies (Oke 1982). The UHI may pose a health risk for urban dwellers because of elevated ambient air temperatures (McGregor et al. 2007). Precipitation patterns have also been shown to be affected by some larger urban heat islands. Within urban areas complex temperature patterns arise from the variability in surface cover, building height, and anthropogenic heat sources, for instance. Urban areas have reduced sky view factors (SVFs) due to many tall buildings, which can contribute to the UHI effect.

\section{Urban local scale}

The urban local scale lies between the urban microscale and the urban mesoscale (see Fig. 2). It represents hourly turbulence of sensible, latent, and storage heat fluxes within a spatial volume of $10^{2}-10^{4} \mathrm{~m}^{3}$, reaching a height up to the inertial sub-layer (Grimmond and Oke 2002; Grimmond et al. 2010). The local scale is characteristic of neighbourhood responses and fluxes (as opposed to yard/ house for urban microscale and region for urban mesoscale). The local scale is contained within the urban boundary layer (UBL), containing both the surface layer and roughness sub-layer (Grimmond and Oke 2002). Both microscale and mesoscale processes of turbulent sensible, latent and storage heat fluxes influence the local scale. Furthermore, the high variability in fluxes found in the urban microscale (roughness sub-layer) — generated by rough/varying topography and building/ground surfacesare less variable at the height of the inertial sub-layer, and can thus be averaged with time. Therefore, there is a neighbourhood response, which is then affected by local weather patterns.

\section{Urban mesoscale}

The urban mesoscale is an intermediate scale, ranging spatially from a few kilometres to several hundred kilometres horizontally, and tens of metres vertically, with a temporal scale of about 1 to $12 \mathrm{~h}$ (Pielke 1984) (see Fig. 2). It lies between the scales of weather systems and of microclimates, within the atmospheric boundary layer (Hang et al. 2009). At this height, factors of urban roughness, terrain, and meteorological conditions are incorporated, while ignoring variability at the neighbourhood (urban local scale) and street-scales (urban microscale). Within mesoscale modelling, the urban-induced dynamical and thermal effects on surface energy budgets are key components in calculations (Arnfield 2003). There is a link in the urban microscales and urban mesoscales, where small effects become greater, particularly the effects of urban canyon radiation geometry and land surface dynamics affecting sensible heat flux (Arnfield 2003). At the mesoscale, interactions with the planetary boundary layer (PBL) are crucial, due to larger circulations, such as mountain/valley flows, land/sea breezes, and urban breezes (Martilli 2007). Mesoscale modelling involves weather forecasts, air quality, storms, and urban climates within the UBL.

\section{Urban microscale}

The urban microscale deals with atmospheric phenomena at length and time scales less than $1 \mathrm{~km}$ and 1 day (AMS 2013). Urban microscale meteorology resides within the roughness sub-layer and smaller urban canopy layer (UCL), in which micrometeorological processes occur (see Fig. 2). However, we are often interested in microscale measurements on the order of centimetres to metres, and seconds to hours. Within these scales, micrometeorologists are interested in partitioning of fluxes of heat, moisture, and gas exchanges from soil, vegetation, water, and ground/building surfaces, thus varying greatly within the same local climate (Oke 1987). Common urban microscale environments include parking lots, streets, open grass and treed green space, urban canyons, small lakes, and backyards. Within this scale, humans have the ability to modify properties so as to improve their thermal comfort. A very influential urban microscale effect is the threedimensional radiative flux, which varies substantially with respect to thermal and reflective properties of urban surfaces (Grimmond et al. 2010). Within the built environment, threedimensional streets and surface-plant-air interactions are increasingly dependent on microscale characteristics under calm, clear, nocturnal conditions, showing stronger dependence on the microscale site characteristics (Grimmond et al. 2010). Additionally, heat and water storage, plus anthropogenic heat fluxes, display significant spatial variability with respect to the morphology and type of the urban surface (Arnfield 2003).

\section{Vector}

1. In atmospheric science, a quantity that possesses a magnitude and a direction (e.g. wind, vorticity, etc.).

2. In biology, an organism that spreads infection by transporting pathogens from one host to another. For example, mosquitoes are vectors of malaria and ticks are vectors of Lyme disease. 


\section{Vernalisation}

The acquisition of a plant's ability to flower or germinate in the spring by exposure to the prolonged cold of winter, often measured with the accumulation of chilling hours/days (below a given threshold) (Chuine 2000; Richardson et al. 2006). Vernalisation is required by many temperate plants for dormancy release (Chouard 1960).

Volatile organic compounds

General term for carbonic matter that easily takes a gaseous state due to a high vapour pressure or a low boiling point. The compounds originate naturally $(90 \%)$ and from human sources $(10 \%)$. Examples of natural compounds are terpenes off-gassing from conifers or the odour of plants in general. Human-produced emissions are of a great variety and can source from solvents of paints and coatings as well as gasoline stations, or automobile exhausts. The presence of volatile organic compounds (VOCs) supports the formation of photochemical smog by affecting the balance of ozone and $\mathrm{NO}_{\mathrm{x}}$ (Shao et al. 2009).

\section{Wet bulb globe temperature}

Applied as an apparent temperature index to set safe limits for physical exertion in the heat. The indoor wet bulb globe temperature (WBGT) index is determined by two single readings: psychrometric wet bulb temperature $\left(T_{\mathrm{w}}\right)$ and black globe temperature $\left(T_{\mathrm{g}}\right)$, as follows:

$W B G T=0.7 \mathrm{~T}_{\mathrm{w}}+0.3 \mathrm{~T}_{\mathrm{g}}$

For outdoors, WBGT is calculated with natural wet bulb temperature $\left(T_{\mathrm{nw}}\right), T_{\mathrm{g}}$ and dry bulb temperature $\left(T_{\mathrm{a}}\right)$ as follows:

$W B G T=0.7 \mathrm{~T}_{n w}+0.2 \mathrm{~T}_{\mathrm{g}}+0.1 \mathrm{~T}_{\mathrm{a}}$

The WBGT is a commonly used index of thermal stress (Budd 2008) but it has recently been reviewed for its limitations and applicability (Budd 2008; Parsons 2006). The ergonomics of the thermal environment standard BS EN ISO 27243:1994 (British Standards Institution 1994) and ISO 7243:1989 (Parsons 2006) is based upon the WBGT.

\section{Wildfire}

The uncontrolled burning of plant matter, often in grasslands, bushlands, and woodlands. Wildfire may be caused by natural phenomena including lightning and volcanic debris as well as by anthropogenic actions. Burn characteristics are dependent on the atmospheric, ecological, and geological properties of the environment. Land use and climate significantly contribute to the fire potential of individual locales (Dominici et al. 2006; Hyndman and Hyndman 2010).

\section{World Health Organization}

The World Health Organization (WHO) is the directing and coordinating authority for health within the United Nations system. It is responsible for providing leadership on global health matters, shaping the health research agenda, setting norms and standards, articulating evidence-based policy options, providing technical support to countries and monitoring and assessing health trends (WHO 2011a). When diplomats met to form the United Nations in 1945, they discussed establishing a global health organization. WHO's Constitution came into force on 7 April 1948 - a date we now celebrate every year as World Health Day. WHO fulfils its objectives through its core functions (WHO 2011a):

- providing leadership on matters critical to health and engaging in partnerships where joint action is needed;

- shaping the research agenda and stimulating the generation, translation and dissemination of valuable knowledge;

- setting norms and standards and promoting and monitoring their implementation;

- articulating ethical and evidence-based policy options;

- providing technical support, catalysing change, and building sustainable institutional capacity;

- monitoring the health situation and assessing health trends.

Acknowledgements Seven anonymous reviewers and the Editor (Scott C. Sheridan) are thanked for their detailed and constructive comments and suggestions on a previous version of the manuscript, which helped to improve the breadth and quality of the Glossary. A special thank you is also directed towards the Executive Board of the International Society of Biometeorology for their advice, inputs and comments on a previous version of the manuscript - in this respect, the authors are particularly grateful to Paul Beggs, Mark D. Schwartz, Laurence S Kalkstein and Glenn R. McGregor. Thank you to the American Meteorological Society for granting permission to reproduce Fig. 2 (Marshall 2004).

Open Access This article is distributed under the terms of the Creative Commons Attribution License which permits any use, distribution, and reproduction in any medium, provided the original author(s) and the source are credited.

\section{References}

Allaby M (2002) Encyclopedia of weather and climate. Facts on File, New York, $667 \mathrm{pp}$

Allen J (1877) The influence of physical conditions in the genesis of species. Rad Rev:108-140

AMS (2013) Glossary of meteorology. American meteorological society. http://amsglossary.allenpress.com/glossary. Accessed 5 July 2013 
Anderson BG, Bell ML (2009) Weather-related mortality: how heat, cold, and heat waves affect mortality in the United States. Epidemiology 20:205-213

Armstrong BK (1994) Stratospheric ozone and health. Int J Epidemiol 23: 873-885

Arnell NW, Lowe JA, Brown S, Gosling SN, Gottschalk P, Hinkel J, Lloyd-Hughes B, Nicholls RJ, Osborn TJ, Osborne TM, Rose GA, Smith P, Warren RF (2013) A global assessment of the effects of climate policy on the impacts of climate change. Nat Clim Chang 3: $512-519$

Arnfield AJ (2003) Two decades of urban climate research: a review of turbulence, exchanges of energy and water, and the urban heat island. Int J Climatol 23:1-26

ASHRAE (2001) ASHRAE Fundamentals handbook 2001 (SI Edition). Chapter 31: Energy estimating and modeling methods. American society of heating, refrigerating, and air-conditioning engineers, Atlanta, GA

ASHRAE (2004) ASHRAE Standard, ANSI/ASHRAE Standard 552004: thermal environmental conditions for human occupancy. American Society of Heating, Refrigerating, and Air-Conditioning Engineers, Atlanta, GA

ASHRAE (2005) ANSI/ASHRAE/IESNA Standard 90.1-2004: I-P Edition. Energy standard for buildings except low-rise residential buildings. American Society of Heating, Refrigerating, and AirConditioning Engineers, Atlanta, GA

Baccini M, Kosatsky T, Analitis A, Anderson HR, D'Ovidio M, Menne B, Michelozzi P, Biggeri A, Group tPC (2011) Impact of heat on mortality in 15 European cities: attributable deaths under different weather scenarios. J Epidemiol Community Health 65:64-70

Baeta FC, Meador NF, Shanklin MD, Johnson HD (1987) Equivalent temperature index at temperatures above the thermoneutral for lactating dairy cows. ASAE Paper No. 874015. St. Joseph, MI

Baker N, Standeven M (1996) Thermal comfort for free-running buildings. Energy Build 23:175-182

Basu R (2009) High ambient temperature and mortality: a review of epidemiologic studies from 2001 to 2008. Environ Heal 8:1-13

Beggs PJ, Vaneckova P (2008) Admission to hospital for effects of heat and light: NSW, 1993-94 to 2003-04. NSW Public Health Bull 19: $132-137$

Belding HS, Hatch TF (1955) Index for evaluating heat stress in terms of resulting physiological strain. Heat Piping Air Cond 27:129

Beniston M (2004) The 2003 heat wave in Europe: A shape of things to come? An analysis based on Swiss climatological data and model simulations. Geophys Res Lett 31

Bergmann C (1847) Über die Verhältnisse der Wärmeökonomie der Thiere zu ihrer Grösse (About the relationship of the animals' economy of warmth to their size). Göttinger Studien 3:595-708

Bianca W (1962) Relative importance of dry- and wet-bulb temperatures in causing heat stress in cattle. Nature 195:251-252

Bishoi B, Prakash A, Jain VK (2009) A comparative study of air quality index based on factor analysis and US-EPA methods for an Urban Environment. Aerosol Air Qual Res 9:1-17

Błażejczyk K, Jendritzky G, Bröde P, Fiala D, Havenith G, Epstein Y, Psikuta A, Kampmann B (2013) An introduction to the Universal Thermal Climate Index (UTCI). Geogr Pol 86:5-10

Bohmanova J, Misztal I, Cole JB (2007) Temperature-humidity indices as indicators of milk production losses due to heat stress. J Dairy Sci 90:1947-1956

Bouchama A, Knochel JP (2002) Heat stroke. N Engl J Med 346:19781988

Brady NC, Weil RR (2002) The nature and properties of soils, 13th edn. Prentice-Hall, Upper Saddle River, 960 pp

Breiman L, Friedman J, Olshen RA, Stone CJ (1984) Classification and regression trees. Wadsworth International Group, Belmont, $368 \mathrm{pp}$
British Standards Institution (1994) BS EN ISO 27243:1994 Hot environments. Estimation of the heat stress on working man, based on the WBGT-index (wet bulb globe temperature). BSI, London, UK. $18 \mathrm{pp}$

British Standards Institution (2002a) BS EN ISO 10551:2001 Ergonomics of the thermal environment-assessment of the influence of the thermal environment using subjective judgement scales. BSI, London, $30 \mathrm{pp}$

British Standards Institution (2002b) BS EN ISO 13731:2002 Ergonomics of the thermal environment-vocabulary and symbols. BSI, London, $48 \mathrm{pp}$

British Standards Institution (2004) BS EN ISO 9886:2004 Ergonomicsevaluation of thermal strain by physiological measurements. BSI, London, $32 \mathrm{pp}$

British Standards Institution (2005a) BS EN ISO 7933:2004 Ergonomics of the thermal environment-analytical determination and interpretation of heat stress using calculation of the predicted heat strain. BSI, London, $46 \mathrm{pp}$

British Standards Institution (2005b) BS EN ISO 8996:2004 Ergonomics of the thermal environment-determination of metabolic rate. BSI, London, $34 \mathrm{pp}$

British Standards Institution (2006) BS EN ISO 7730:2005 Ergonomics of the thermal environment-analytical determination and interpretation of thermal comfort using calculation of the PMV and PPD indices and local thermal comfort criteria. BSI, London, $64 \mathrm{pp}$

British Standards Institution (2008) BS EN ISO 11079:2007 Ergonomics of the thermal environment-determination and interpretation of cold stress when using required clothing insulation (IREQ) and local cooling effects. BSI, London, UK. 46 pp

British Standards Institution (2009a) BS EN ISO 9920:2009 Ergonomics of the thermal environment-estimation of thermal insulation and water vapour resistance of a clothing ensemble. BSI, London, $114 \mathrm{pp}$

British Standards Institution (2009b) BS EN ISO 13732-1:2008 Ergonomics of the thermal environment-methods for the assessment of human responses to contact with surfaces-Part 1: Hot surfaces. BSI, London, $46 \mathrm{pp}$

British Standards Institution (2009c) BS EN ISO 13732-3:2008 Ergonomics of the thermal environment-methods for the assessment of human responses to contact with surfaces-Part 3: Cold surfaces. BSI, London, $32 \mathrm{pp}$

British Standards Institution (2013) BS EN ISO 13732-2:2001 Ergonomics of the thermal environment-methods for the assessment of human responses to contact with surfaces-Part 2: Human contact with surfaces at moderate temperature. BSI, London, $22 \mathrm{pp}$

Broom DM (1991) Animal welfare: concepts and measurement. J Anim Sci 69:4167-4175

Brotherhood JR (2008) Heat stress and strain in exercise and sport. J Sci Med Sport 11:6-19

Budd GM (2008) Wet-bulb globe temperature (WBGT) - its history and its limitations. J Sci Med Sport 11:20-32

Burge PS (2004) Sick building syndrome. Occup Environ Med 61:185-190

Campbell NA (1996) Biology. Cumming, Menlo Park, 1206 pp

CDC (2005) Hypothermia-related deaths-United States, 2003-2004. MMWR Morb Mortal Wkly Rep 54:173-175

CDC (2011) Facts About Benzene. United States Centers for Disease Control and Prevention. http://www.bt.cdc.gov/agent/benzene/ basics/facts.asp. Accessed May 2011

CDC (2013) Reproductive health: Glossary. http://www.cdc.gov/ reproductivehealth/EpiGlossary/glossary.htm. Accessed 5 July 2013

Chauhan AJ, Krishna MT, Frew AJ, Holgate ST (1998) Exposure to nitrogen dioxide (NO2) and respiratory disease risk. Rev Environ Heal 13:73-90

Chouard P (1960) Vernalization and its relations to dormancy. Annu Rev Plant Physiol 11:191-238

Chuine I (2000) A unified model for Budburst of trees. J Theor Biol 207: $337-347$ 
Cleland EE, Chuine I, Menzel A, Mooney HA, Schwartz MD (2007) Shifting plant phenology in response to global change. Trends Ecol Evol 22:357-365

COST (2011) COST Action 730. http://www.utci.org/cost.php. Accessed 13 June 2011

D’Amato G, Cecchi L, Bonini S, Nunes C, Annesi-Maesano I, Behrendt H, Liccardi G, Popov T, Van Cauwenberge P (2007) Allergenic pollen and pollen allergy in Europe. Allergy 62:976-990

Da Silva RG, Maia ASC (2013) Principles of animal biometeorology. Springer, New York, $261 \mathrm{pp}$

Davie T (2008) Fundamentals of hydrology. Routledge Fundamentals of Physical Geography Series. Routledge, London. 200 pp

Davis RE, Knappenberger PC, Novicoff WM, Michaels PJ (2002) Decadal changes in heat-related human mortality in the eastern United States. Clim Res 22:175-184

de Freitas CR, Scott D, McBoyle G (2008) A second generation climate index for tourism (CIT): specification and verification. Int $\mathrm{J}$ Biometeorol 52:399-407

Defila C, Clot B (2001) Phytophenological trends in Switzerland. Int J Biometeorol 45:203-207

DeShazer JA, Hahn GL, Xin H (2009) Basic principles of the thermal environment and livestock energetics. In: DeShazer JA (ed) Livestock energetics and thermal environment management. ASABE, Idaho, pp 1-22

Dominici F, Peng RD, Bell ML, Pham L, McDermott A, Zeger SL, Samet JM (2006) Fine particulate air pollution and hospital admission for cardiovascular and respiratory diseases. JAMA 295:11271134

Duflo E, Greenstone M, Hanna R (2008) Indoor air pollution, health and economic well-being. Surveys and Perspectives Integrating Environment and Society 1:1-9

Ebi KL, Teisberg TJ, Kalkstein LS, Robinson L, Weiher RF (2004) Heat watch/warning systems save lives: estimated costs and benefits for Philadelphia 1995-98. Bull Am Meteorol Soc 85: $1067-1073$

Ellefsen R (1991) Mapping and measuring buildings in the canopy boundary layer in ten US cities. Energy Build 16:1025-1049

Elliott S, Baker PJ, Borchert R (2006) Leaf flushing during the dry season: the paradox of Asian monsoon forests. Glob Ecol Biogeogr $15: 248-257$

Eriksson NE, Holmen A (1996) Skin prick tests with standardized extracts of inhalant allergens in 7099 adult patients with asthma or rhinitis: cross-sensitizations and relationships to age, sex, month of birth and year of testing. J Investig Allergol Clin Immunol 6:36-46

Fanger PO (1967) Calculation of thermal comfort: introduction of a basic comfort equation. ASHRAE Trans 73:III.4.1-III.4.20

Fanger PO (1972) Thermal comfort: Analysis and applications in environmental engineering. McGraw Hill, NewYork, 244 pp

FAO (2013) FAO (Food and Agriculture Organization of the United Nations) Penman-Monteith equation. http://www.fao.org/docrep/ x0490e/x0490e06.htm. Accessed 11 July 2013

Freidhoff LR, Ehrlichkautzky E, Grant JH, Meyers DA, Marsh DG (1986) A study of the human immune response to Lolium perenne (Rye) pollen and its components, Lolp I and Lolp II (Rye I and Rye II). Prevalence of reactivity to the allergens and correlations among skin test, IgE antibody, and IgG antibody data. J Allergy Clin Immunol 78:1190-1201

Friedl M, Henebry G, Reed B, Huete A, White M, Morisette J, Nemani R, Zhang X, Myneni R (2006) Land surface phenology. A Community White Paper requested by NASA

Fuquay JW (1981) Heat stress as it affects animal production. J Anim Sci 52:164-174

Gagge AP, Fobelets A, Berglund LG (1986) A standard predictive index of human response to the thermal environment. ASHRAE Trans 92: 709-731
Gagge AP, Stolwijk JAJ, Nishi Y (1972) An effective temperature scale based on a simple model of human physiological regulatiry response. ASHRAE Trans 77:247-257

Gaughan JB, Mader TL, Holt SM, Lisle A (2008) A new heat load index for feedlot cattle. J Anim Sci 86:226-234

Gonçalves FLT, Braun S, Dias PLS, Sharovsky R (2007) Influences of the weather and air pollutants on cardiovascular disease in the metropolitan area of Sao Paulo. Environ Res 104:275-281

Gosling SN, Arnell NW (2011) Simulating current global river runoff with a global hydrological model: model revisions, validation, and sensitivity analysis. Hydrol Processes 25:1129-1145

Gosling SN, Lowe JA, McGregor GR, Pelling M, Malamud B (2009) Associations between elevated atmospheric temperature and human mortality: a critical review of the literature. Clim Chang 92:299-341

Gosling SN, McGregor GR, Paldy A (2007) Climate change and heatrelated mortality in six cities Part 1: model construction and validation. Int J Biometeorol 51:525-540

Gouveia N, Hajat S, Armstrong B (2003) Socioeconomic differentials in the temperature-mortality relationship in São Paulo, Brazil. Int J Epidemiol 32:390-397

Grimmond CSB, Oke TR (2002) Turbulent heat fluxes in urban areas: observations and a local-scale urban meteorological parameterization scheme (LUMPS). J Appl Meteorol 41:792-810

Grimmond CSB, Roth M, Oke TR, Au YC, Best M, Betts R, Carmichael G, Cleugh H, Dabberdt W, Emmanuel R, Freitas E, Fortuniak K, Hanna S, Klein P, Kalkstein LS, Liu CH, Nickson A, Pearlmutter D, Sailor D, Voogt J (2010) Climate and more sustainable cities: climate information for improved planning and management of cities (producers/capabilities perspective). Procedia Environ Sci 1: 247-274

Hajat S, Kovats RS, Atkinson RW, Haines A (2002) Impact of hot temperature on death in London: a time series approach. J Epidemiol Community Health $56: 367-372$

Hang J, Sandberg M, Li Y, Claesson L (2009) Pollutant dispersion in idealized city models with different urban morphologies. Atmos Environ 43:6011-6025

Harris JG, Harris MW (1997) Plant identification terminology: an illustrated glossary. Spring Lake, Spring Lake, UT, 197 pp

Harrison RM, Yamulki S, Goulding KWT, Webster CP (1995) Effect of fertilizer application on $\mathrm{NO}$ and $\mathrm{N} 2 \mathrm{O}$ fluxes from agricultural fields. J Geophys Res Atmos 100:25923-25931

Hassi J (2005) Cold extremes and impacts on health. In: Kirch W, Bertollini R, Menne B (eds) Extreme weather events and public health responses. Springer, Heidelberg, pp 59-67

Hastie T, Tibshirani R (1990) Generalized additive models. Chapman and Hall, London, $352 \mathrm{pp}$

Havenith G, Fiala D, Błazejczyk K, Richards M, Bröde P, Holmér I, Rintamaki H, Benshabat Y, Jendritzky G (2012) The UTCI-clothing model. Int J Biometeorol 56:461-470

Heath J, Ayres E, Possell M, Bardgett RD, Black HIJ, Grant H, Ineson P, Kerstiens G (2005) Rising atmospheric CO2222 reduces sequestration of root-derived soil carbon. Science 309:1711-1713

Henry J (1992) Biological basis of the stress response. Integr Physiol Behav Sci 27:66-83

Holgate S (2011) Review of the UK Air quality index. A report by the Committee on the medical effects of air pollutants. Health Protection Agency, London, $118 \mathrm{pp}$

Hondula DM, Vanos JK, Gosling SN (2013) The SSC: a decade of climatehealth research and future directions. Int J Biometeorol:1-12

Höppe P (1999) The physiological equivalent temperature - a universal index for the biometeorological assessment of the thermal environment. Int J Biometeorol 43:71-75

Hyndman D, Hyndman D (2010) Natural hazards and disasters. Brooks/ Cole Pub Co. 592 pp

International Society of Biometeorology (ISB) (2013) What is biometeorology? http://biometeorology.org/what_is_bm/index.cfm. 
IPCC (2007) Climate Change 2007: The physical science basis. contribution of working group $i$ to the fourth assessment report of the intergovernmental panel on climate change. Cambridge University Press, Cambridge, $996 \mathrm{pp}$

IPCC (2012a) Authors and expert reviewers annex. Managing the risks of extreme events and disasters to advance climate change adaptation. In: Field CB, Barros V, Stocker TF et al (eds) A special report of working groups I and II of the Intergovernmental Panel on Climate Change (IPCC). Cambridge University Press, Cambridge, pp 545-553

IPCC (2012b) Summary for policymakers. Managing the risks of extreme events and disasters to advance climate change adaptation. In: Field CB, Barros V, Stocker TF et al (eds) A special report of working groups I and II of the Intergovernmental Panel on Climate Change (IPCC). Cambridge University Press, Cambridge, pp 1-19

IUPS Thermal Commission IUPS (2001) The commission for thermal physiology of the International Union of Physiological Sciences (IUPS). Glossary of terms for thermal physiology, 3rd edn. Jpn J Physiol 51:245-280

Jendritzky G, de Dear R (2009) Adaptation and thermal environment. In: Ebi KL, Burton I, McGregor GR (eds) Biometeorology for adaptation to climate variability and change, vol 1. Biometeorology. Springer, Netherlands, pp 9-32

Jendritzky G, Dear R, Havenith G (2012) UTCI - Why another thermal index? Int J Biometeorol 56:421-428

Jendritzky G, Menz G, Schmidt-Kessen W, Schirmer H (1990) Methodik zur räumlichen Bewertung der thermischen Komponente im Bioklima des Menschen. Akademie für Raumforschung und Landesplanung, Hannover

Jendritzky G, Sönning W, Swantes H (1979) Ein objektives Bewertungsverfahren zur Beschreibung des thermischen Milieus in der Stadt- und Landschaftsplanung (Klima-Michel-Modell). vol 28. Beiträge der Akademie für Raumforschung und Landesplanung, Hannover

Kalkstein LS, Greene S, Mills DM, Samenow J (2011) An evaluation of the progress in reducing heat-related human mortality in major US cities. Nat Hazard 56:113-129

Kalkstein LS, Nichols MC, Barthel CD, Greene JS (1996) A new spatial synoptic classification: application to air mass analysis. Int $\mathrm{J}$ Climatol 16:983-1004

Kappos AD, Bruckmann P, Eikmann T, Englert N, Heinrich U, Höppe P, Koch E, Krause GHM, Kreyling WG, Rauchfuss K (2004) Health effects of particles in ambient air. Int J Hyg Environ Health 207: 399-407

Keatinge WR, Donaldson GC, Cordioli E, Martinelli M, Kunst AE, Mackenbach JP, Nayha S, Vuori I (2000) Heat related mortality in warm and cold regions of Europe: observational study. BMJ 321: 670-673

Kingston DG, Todd MC, Taylor RG, Thompson JR, Arnell NW (2009) Uncertainty in the estimation of potential evapotranspiration under climate change. Geophys Res Lett 36, L20403

Kleidon A, Heimann M (1996) Simulating root carbon storage with a coupled carbon-water cycle root model. Phys Chem Earth 21:499-502

Klemm O, Milford C, Sutton MA, Spindler G, van Putten E (2002) A climatology of leaf surface wetness. Theor Appl Climatol 71:107-117

Koppe C, Jendritzky G (2005) Inclusion of short-term adaptation to thermal stresses in a heat load warning procedure. Meteorol Z 14:271-278

Koppe C, Kovats R, Jendritzky G, Menna B (2004) Health and global environmental change series, No. 2. WHO Regional Office for Europe, Copenhagen

Kovats RS, Ebi KL (2006) Heatwaves and public health in Europe. Eur J Pub Health 16:592-599

Kregel KC (2002) Invited review: heat shock proteins: modifying factors in physiological stress responses and acquired thermotolerance. J Appl Physiol 92:2177-2186
Kyrkilis G, Chaloulakou A, Kassomenos PA (2007) Development of an aggregate air quality index for an urban Mediterranean agglomeration: relation to potential health effects. Environ Int 33:670-676

Laaidi M (2001) Forecasting the start of the pollen season of Poaceæ: evaluation of some methods based on meteorological factors. Int $\mathrm{J}$ Biometeorol 45:1-7

Lasiewski RC, Bernstein MH, Ohmart RD (1971) Cutaneous water loss in the roadrunner and poor-will. Condor 73:470-478

Le Tertre A, Lefranc A, Eilstein D, Declercq C, Medina S, Blanchard M, Chardon B, Fabre P, Filleul L, Jusot JF, Pascal L, Prouvost H, Cassadou S, Ledrans M (2006) Impact of the 2003 heatwave on all-cause mortality in 9 French cities. Epidemiology 17:75-79

Lebourgeois F, Pierrat J-C, Perez V, Piedallu C, Cecchini S, Ulrich E (2010) Simulating phenological shifts in French temperate forests under two climatic change scenarios and four driving global circulation models. Int J Biometeorol 54:563-581

Levine JS, Augustsson TR, Andersont IC, Hoell JM Jr, Brewer DA (1984) Tropospheric sources of NOx: lightning and biology. Atmos Environ 18:1797-1804

Liang L, Schwartz M (2009) Landscape phenology: an integrative approach to seasonal vegetation dynamics. Landsc Ecol 24:465-472

Lin TP, Matzarakis A (2008) Tourism climate and thermal comfort in Sun Moon Lake, Taiwan. Int J Biometeorol 52:281-290

Lindsay SL (1987) Geographic size and non-size variation in Rocky Mountain Tamiasciurus hudsonicus: significance in relation to Allen's rule and vicariant biogeography. J Mammal 68:39-48

Loomis D, Richardson DB, Elliott L (2005) Poisson regression analysis of ungrouped data. Occup Environ Med 62:325-329

Ma W, Yang C, Tan J, Song W, Chen B, Kan H (2011) Modifiers of the temperature-mortality association in Shanghai, China. Int $\mathrm{J}$ Biometeorol:1-3

Magnuson JJ, Robertson DM, Benson BJ, Wynne RH, Livingstone DM, Arai T, Assel RA, Barry RG, Card V, Kuusisto E, Granin NG, Prowse TD, Stewart KM, Vuglinski VS (2000) Historical trends in lake and river ice cover in the Northern Hemisphere. Science 289:1743-1746

Mahillon V, Saussez S, Michel O (2006) High incidence of sensitization to ornamental plants in allergic rhinitis. Allergy 61:1138-1140

Maia ASC, Silva RG, Loureiro CMB (2005) Sensible and latent heat loss from the body surface of Holstein cows in a tropical environment. Int J Biometeorol 50:17-22

Marshall SJ (2004) A review of current investigations of urban-induced rainfall and recommendations for the future. Earth Interact 9:1-27

Martilli A (2007) Current research and future challenges in urban mesoscale modelling. Int J Climatol 27:1909-1918

Martin S, Cakmak S, Hebbern C, Avramescu M-L, Tremblay N (2012) Climate change and future temperature-related mortality in $15 \mathrm{Ca}-$ nadian cities. Int J Biometeorol 56:605-619

Masson V (2000) A physically-based scheme for the urban energy budget in atmospheric models. Bound-Layer Meteorol 94:357-397

Masterson J, Richardson FA (1979) Humidex. A method of quantifying human discomfort due to excessive heat and humidity. Environment Canada, Downsview

Matzarakis A, Amelung B (2008) Physiological equivalent temperature as indicator for impacts of climate change on thermal comfort of humans seasonal forecasts, climatic change and human health. In: Thomson MC, Garcia-Herrera R, Beniston M (eds) Advances in global change research, vol 30. Springer, Netherlands, pp 161-172

Matzarakis A, Muthers S, Koch E (2010) Human biometeorological evaluation of heat-related mortality in Vienna. Theor Appl Climatol 105:1-10

Matzarakis A, Rocco M, Najjar G (2009) Thermal bioclimate in Strasbourg - the 2003 heat wave. Theor Appl Climatol 98:209-220

McArthur AJ (1987) Thermal interaction between animal and microclimate: a comprehensive model. J Theor Biol 126:203-238

McGregor G (2012a) Special issue: Universal Thermal Comfort Index (UTCI). Int J Biometeorol 56:419 
McGregor GR (2012b) Human biometeorology. Prog Phys Geogr 36:93-109

McGregor GR (2005) Winter North Atlantic oscillation, temperature and ischaemic heart disease mortality in three English counties. Int $\mathrm{J}$ Biometeorol 49:197-204

McGregor GR, Pelling M, Wolf T, Gosling SN (2007) The social impacts of heat waves. Environment Agency, Bristol, $41 \mathrm{pp}$

McMaster GS, Wilhelm WW (1997) Growing degree-days: one equation, two interpretations. Agric For Meteorol 87:291-300

Menzel A (2000) Trends in phenological phases in Europe between 1951 and 1996. Int J Biometeorol 44:76-81

Menzel A, Jakobi G, Ahas R, Scheifinger H, Estrella N (2003) Variations of the climatological growing season (1951-2000) in Germany compared with other countries. Int J Climatol 23:793-812

Michelozzi P, Kirchmayer U, Katsouyanni K, Biggeri A, Bertollini R, Anderson RH, Menne B, McGregor G, Kassomenos P (2004) The PHEWE project - assessment and prevention of acute health effects of weather conditions in Europe. Epidemiology 15:S102-S103

Mieczkowski Z (1985) The tourism climatic index: a method of evaluating world climates for tourism. Can Geogr-Geogr Can 29:220-233

Mills G (1997) An urban canopy-layer climate model. Theor Appl Climatol 57:229-244

Mokdad A, Serdula MK, Dietz WH, Bowman BA, Marks JS, Koplan JP (1999) The spread of the obesity epidemic in the United States, 1991-1998. JAMA 282:1519-1522

Monteith J (1965) Evaporation and environment. Proc Symp Exp Biol 19:205-234

Moonen AC, Ercoli L, Mariotti M, Masoni A (2002) Climate change in Italy indicated by agrometeorological indices over 122 years. Agric For Meteorol 111:13-27

Morabito M, Crisci A, Cecchi L, Modesti P, Maracchi G, Gensini G, Orlandini S (2008) A biometeorological procedure for weather forecast to assess the optimal outdoor clothing insulation. Eur J Appl Physiol 104:221-228

NASA (2013) Landsat Science. http://landsat.gsfc.nasa.gov/. Accessed 23 Sept 2013

National Research Council (1971) A guide to environmental research on animals. National Academy of Sciences, Washington

Näyhä S, Hassi J, Jousilahti P, Laatikainen T, Ikäheimo TM (2011) Cold-related symptoms among the healthy and sick of the general population: national FINRISK Study data, 2002. Public Health 125:380-388

Nicol JF, Humphreys MA (2002) Adaptive thermal comfort and sustainable thermal standards for buildings. Energy Build 34:563-572

Nikolopoulou M, Baker N, Steemers K (2001) Thermal comfort in outdoor urban spaces: understanding the human parameter. Sol Energy 70:227-235

NOAA (2011) Windchill: Frequently asked questions, terms and definitions. http://www.weather.gov/om/windchill/. Accessed 13 June 2011

NOAA (2013) Heating and Cooling Degree Day Data. http://www.ncdc. noaa.gov/oa/documentlibrary/hcs/hcs.html. Accessed 10 July 2013

Norbäck D (2009) An update on sick building syndrome. Curr Opin Allergy Clin Immunol 9:55-59

Novak M (2013) Use of the UTCI in the Czech Republic. Geogr Pol 86:21-28

Oh J-W, Lee H-B, Kang I-J, Kim S-W, Park K-S, Kook M-H, Kim B-S, Baek H-S, Kim J-H, Kim J-K, Lee D-J, Kim K-R, Choi Y-J (2012) The revised edition of Korean calendar for allergenic pollens. Allergy Asthma Immunol Res 4:5-11

Oke TR (1976) The distinction between canopy and boundary-layer urban heat islands. Atmosphere 14:268-277

Oke TR (1982) The energetic basis of the urban heat island. Q J R Meteorol Soc 108:1-24

Oke TR (1987) Boundary layer climates, 2nd edn. Routledge, London, $464 \mathrm{pp}$

Oke TR (1997) Urban environments. In: Bailey WG, Oke TR, Rouse WR (eds) The surface climates of Canada. McGill/Queens University Press, Montreal, pp 303-327
Oke TR (2004) Initial guidance to obtain representative meteorological observations at urban sites. IOM Report No. 81. Geneva, Switzerland

Orosa J, Oliveira A (2012) Indoor air standards and models. In: passive methods as a solution for improving indoor environments. Green Energy and Technology. Springer, London, pp 15-47

Osczevski R, Bluestein M (2005) The new wind chill equivalent temperature chart. Bull Am Meteorol Soc 86:1453-1458

Ou C-Q, Song Y-F, Chau Y-K, Yang L, Wong C-M, Chen P-Y (2011) Cold and winter mortality from cardiovascular diseases in Guangzhou, China. Epidemiology 22:S25

Parmesan C, Yohe G (2003) A globally coherent fingerprint of climate change impacts across natural systems. Nature 421:37-42, http:// www.nature.com/nature/journal/v421/n6918/suppinfo/ nature01286 S1.html

Parsons K (2006) Heat stress standard ISO 7243 and its global application. Ind Heal 44:368-379

Parsons K (2010) Human thermal environments: The effects of hot, moderate, and cold environments on human health, comfort and performance. Taylor and Francis, London, 537 pp

Penman H (1948) Natural evaporation from open water, bare soil and grass. Proc R Soc Ser A 193:120-145

Petralli M, Massetti L, Orlandini S (2011) Five years of thermal intraurban monitoring in Florence (Italy) and application of climatological indices. Theor Appl Climatol 104:349-356

Pielke RA (1984) Mesoscale meteorological modelling. Academic, Orlando, $676 \mathrm{pp}$

Plummer LE, Pinkerton KE, Madl AK, Wilson DW (2011) Effects of nanoparticles on the pulmonary vasculature. In: Cardiovascular effects of inhaled ultrafine and nanosized particles. Wiley, New York, pp 317-350

Porta MS (2008) A dictionary of epidemiology. Oxford University Press, USA, $289 \mathrm{pp}$

Raupach M (1979) Anomalies in flux-gradient relationships over forest. Bound-Layer Meteorol 16:467-486

Rauschenbach JO, Yerokhin PI (1975) Quantitative estimation of heat tolerance in animals. Novosibirsk Publishing House Nauka

Revell LE, Bodeker GE, Smale D, Lehmann R, Huck PE, Williamson BE, Rozanov E, Struthers H (2012) The effectiveness of $\mathrm{N}_{2} \mathrm{O}$ in depleting stratospheric ozone. Geophys Res Lett 39, L15806

Richards SA (1976) Evaporative water loss in domestic fowls and its partition in relation to ambient temperature. J Agric Sci 87: $527-532$

Richardson AD, Bailey AS, Denny EG, Martin CW, O'Keefe J (2006) Phenology of a northern hardwood forest canopy. Glob Chang Biol 12:1174-1188

Ricklefs R, Miller G (1999) Ecology. Freeman, New York, 822 pp

Robinson PJ (2001) On the definition of a heat wave. J Appl Meteorol 40: $762-775$

Roth M (2000) Review of atmospheric turbulence over cities. Q J R Meteorol Soc 126:941-990

Rothfusz L (1990) The heat index "equation" (or, more than you ever wanted to know about heat index). National Weather Service Technical Attachment SR 90-23. National Weather Service, USA

Rötzer T, Grote R, Pretzsch H (2004) The timing of bud burst and its effect on tree growth. Int J Biometeorol 48:109-118

Running SW (2008) Ecosystem disturbance, carbon, and climate. Science 321:652-653

Sartor F, Snacken R, Demuth C, Walckiers D (1995) Temperature, ambient ozone levels, and mortality during summer, 1994, in Belgium. Environ Res 70:105-113

Schulte PA, Trout DB (2011) Nanomaterials and worker health: medical surveillance, exposure registries, and epidemiologic research. J Occup Environ Med 53:S3-S7

Schwartz MD (2003) Phenology: an integrative environmental science. Springer, Dordrecht, $564 \mathrm{pp}$ 
Schwartz MD, Ahas R, Aasa A (2006) Onset of spring starting earlier across the Northern Hemisphere. Glob Chang Biol 12:343-351

Schwartz MD, Reiter BE (2000) Changes in North American spring. Int J Climatol 20:929-932

Shao M, Zhang Y, Zeng L, Tang X, Zhang J, Zhong L, Wang B (2009) Ground-level ozone in the Pearl River Delta and the roles of VOC and NOx in its production. J Environ Manage 90:512-518

Shepherd MF, Barzetti S, Hastie DR (1991) The production of atmospheric NOx and $\mathrm{N} 2 \mathrm{O}$ from a fertilized agricultural soil. Atmos Environ Part A Gen Top 25:1961-1969

Sheridan SC (2002) The redevelopment of a weather type classification scheme for North America. Int J Climatol 22:51-68

Shingleton A (2010) Allometry: the study of biological scaling. NatEduc Knowl 3:2

Shitzer A, Tikuisis P (2012) Advances, shortcomings, and recommendations for wind chill estimation. Int J Biometeorol 56:495-503

Silva RG (1973) Improving tropical beef cattle by simultaneous selection for weight and heat tolerance. Heritabilities and correlations of the traits. J Anim Sci 37:637-642

Silva RG, Barbosa OR Thermal comfort index for sheep. In: Proc. 13th International Congress of Biometeorology, Calgary, 12-18 September 1993. pp 383-392

Simelton E, Fraser EDG, Termansen M, Benton TG, Gosling SN, South A, Arnell NW, Challinor AJ, Dougill AJ, Forster PM (2012) The socioeconomics of food crop production and climate change vulnerability: a global scale quantitative analysis of how grain crops are sensitive to drought. Food Security 4:163-179

Singh AB, Mathur C (2012) An aerobiological perspective in allergy and asthma. Asia Pac Allergy 2:210

Snedecor G, Cochran W (1980) Statistical methods. Iowa State University Press. 503 pp

Souch C, Grimmond CSB (2004) Applied climatology: heat waves. Prog Phys Geogr 28:599-606

Spronken-Smith R, Oke T (1998) The thermal regime of urban parks in two cities with different summer climates. Int J Remote Sens 19: 2085-2104

Spronken-Smith R, Oke T (1999) Scale modelling of nocturnal cooling in urban parks. Bound-Layer Meteorol 93:287-312

Staiger H, Laschewski G, Grätz A (2011) The perceived temperature-a versatile index for the assessment of the human thermal environment. Part A: scientific basics. Int J Biometeoro 1:1-12

Steadman R (1979a) The assessment of sultriness. Part II: effects of wind, extra radiation and barometric pressure on apparent temperature. $\mathrm{J}$ Appl Meteorol 18:878-885

Steadman RG (1979b) The assessment of sultriness. Part I: a temperaturehumidity index based on human physiology and clothing science. J Appl Meteorol 18:861-873

Steadman RG (1984) A universal scale of apparent temperature. J Clim Appl Meteorol 23:1674-1687

Stewart I, Oke T Classifying urban climate field sites by "local climate zones": The case of Nagano, Japan. In: Seventh International Conference on Urban Climate, Yokohama, Japan, June 29-July 3 2009a

Stewart I, Oke T Newly developed "thermal climate zones" for defining and measuring urban heat island magnitude in the canopy layer. In: Eighth Symposium on Urban Environment, Phoenix, AZ, January $11-152009 b$

Stewart ID Thermal differentiation of" local climate zones" using temperature observations from urban and rural field sites. In: Ninth Symposium on Urban Environment, Keystone, CO, 2-6 August 2010

Sunyer J, Castellsague J, Saez M, Tobias A, Anto JM (1996) Air pollution and mortality in Barcelona. J Epidemiol Community Health 50: S76-S80
Thakore S, Bhatt B (2007) Introduction to process engineering and design. McGraw-Hill, New York. 748 pp

Thom EC (1959) The discomfort index. Weatherwise 12:57-61

Thornthwaite C (1944) A contribution to the report of the committee on transpiration and evaporation, 1943-1944. Trans Am Geophys Union 25:686-693

Tilkens MJ, Wall-Scheffler C, Weaver TD, Steudel-Numbers K (2007) The effects of body proportions on thermoregulation: an experimental assessment of Allen's rule. J Hum Evol 53:286-291

UN Environment Program (1998) Environmental effects of ozone depletion: 1998 Assessment. Nairobi, Kenya. 193 pp

US Environmental Protection Agency (2010) An introduction to indoor air quality (IAQ). http://www.epa.gov/iaq/ia-intro.html. Accessed July 82011

USA-NPN (National Phenology Network) (2013) Glossary. https://http:// www.usanpn.org/glossary. Accessed 11 July 2013

Valtorta SE, Leva PE, Gallardo MR, Scarpati OE Milk production responses during heat waves events in Argentina. In: Proceedings of the 16th International Congress on Biometeorology, Kansas City, USA, 27 October-1 November 2002. pp 98-101

Vanos JK, Warland JS, Gillespie TJ, Kenny NA (2012) Improved predictive ability of climate-human-behaviour interactions with modifications to the COMFA outdoor energy budget model. Int $\mathbf{J}$ Biometeorol 56:1065-1074

Watson RT, Noble IR, Bolin B, Ravindranath N, Verardo DJ, Dokken DJ (2000) Land use, land-use change and forestry: a special report of the Intergovernmental Panel on Climate Change. Land use, land-use change and forestry: a special report of the Intergovernmental Panel on Climate Change. Cambridge University Press, Cambridge, $30 \mathrm{pp}$

Watts JD, Kalkstein LS (2004) The development of a warm-weather relative stress index for environmental applications. J Appl Meteorol 43:503-513

West GB, Brown JH, Enquist BJ (1997) A general model for the origin of allometric scaling laws in biology. Science 276:122-126

WHO (2003) Health aspects of air pollution with particulate matter, ozone and nitrogen dioxide. Report on a WHO Working Group (EUR/03/5042688). WHO Regional Office for Europe, Copenhagen, Denmark. 98 pp

WHO (2004) Heat-waves: risks and responses. World Health Organization, Copenhagen, $124 \mathrm{pp}$

WHO (2006) Air quality guidelines - global update 2005. World Health Organization, Copenhagen

WHO (2011a) About WHO. http://www.who.int/about/en/. Accessed 18 March 2011

WHO (2011b) International Statistical Classification of Diseases and Related Health Problems. 10th Revision., vol 2. World Health Organization, Geneva, Switzerland. $195 \mathrm{pp}$

WHO (2013) About EuroHEAT. http://www.euro.who.int/en/what-wedo/health-topics/environment-and-health/Climate-change/activities/ prevention,-preparedness-and-response/heathealth-action-plans/ about-euroheat. Accessed 11 July 2013

Wilks DS (1995) Statistical methods in the atmospheric sciences: An introduction. Academic, London, $467 \mathrm{pp}$

Wong TW, Tam WS, Yu TS, Wong AHS (2002) Associations between daily mortalities from respiratory and cardiovascular diseases and air pollution in Hong Kong, China. Occup Environ Med 59:30-35

Yousef MK (1985) Stress physiology in livestock. CRC, Boca Raton

Zhang L, Jacob DJ, Knipping EM, Kumar N, Munger JW, Carouge CC, van Donkelaar A, Wang YX, Chen D (2012) Nitrogen deposition to the United States: distribution, sources, and processes. Atmos Chem Phys Discuss 12:241-282 